\title{
Global cloud top height retrieval using SCIAMACHY limb spectra: model studies and first results
}

\author{
Kai-Uwe Eichmann ${ }^{1}$, Luca Lelli ${ }^{1}$, Christian von Savigny ${ }^{2}$, Harjinder Sembhi ${ }^{3}$, and John P. Burrows ${ }^{1}$ \\ ${ }^{1}$ Institute of Environmental Physics, University of Bremen, Bremen, Germany \\ ${ }^{2}$ Institute of Physics, Ernst Moritz Arndt University of Greifswald, Greifswald, Germany \\ ${ }^{3}$ Earth Observation Science, University of Leicester, Leicester, UK \\ Correspondence to: Kai-Uwe Eichmann (eichmann@uni-bremen.de)
}

Received: 5 May 2015 - Published in Atmos. Meas. Tech. Discuss.: 10 August 2015

Revised: 8 January 2016 - Accepted: 8 February 2016 - Published: 2 March 2016

\begin{abstract}
Cloud top heights (CTHs) are retrieved for the period 1 January 2003 to 7 April 2012 using height-resolved limb spectra measured with the SCanning Imaging Absorption SpectroMeter for Atmospheric CHartographY (SCIAMACHY) on board ENVISAT (ENVIronmental SATellite). In this study, we present the retrieval code SCODA (SCIAMACHY cloud detection algorithm) based on a colour index method and test the accuracy of the retrieved CTHs in comparison to other methods.

Sensitivity studies using the radiative transfer model SCIATRAN show that the method is capable of detecting cloud tops down to about $5 \mathrm{~km}$ and very thin cirrus clouds up to the tropopause. Volcanic particles can be detected that occasionally reach the lower stratosphere. Upper tropospheric ice clouds are observable for a nadir cloud optical thickness $(\mathrm{COT}) \geq 0.01$, which is in the subvisual range. This detection sensitivity decreases towards the lowermost troposphere. The COT detection limit for a water cloud top height of $5 \mathrm{~km}$ is roughly 0.1 . This value is much lower than thresholds reported for passive cloud detection methods in nadir-viewing direction. Low clouds at 2 to $3 \mathrm{~km}$ can only be retrieved under very clean atmospheric conditions, as light scattering of aerosol particles interferes with the cloud particle scattering.

We compare co-located SCIAMACHY limb and nadir cloud parameters that are retrieved with the Semi-Analytical CloUd Retrieval Algorithm (SACURA). Only opaque clouds $\left(\tau_{\mathrm{N}, \mathrm{c}}>5\right)$ are detected with the nadir passive retrieval technique in the UV-visible and infrared wavelength ranges. Thus, due to the frequent occurrence of thin clouds and subvisual cirrus clouds in the tropics, larger CTH deviations are detected between both viewing geometries. Zonal mean CTH
\end{abstract}

differences can be as high as $4 \mathrm{~km}$ in the tropics. The agreement in global cloud fields is sufficiently good. However, the land-sea contrast, as seen in nadir cloud occurrence frequency distributions, is not observed in limb geometry. Colocated cloud top height measurements of the limb-viewing Michelson Interferometer for Passive Atmospheric Sounding (MIPAS) on ENVISAT are compared for the period from January 2008 to March 2012. The global CTH agreement of about $1 \mathrm{~km}$ is observed, which is smaller than the vertical field of view of both instruments.

Lower stratospheric aerosols from volcanic eruptions occasionally interfere with the cloud retrieval and inhibit the detection of tropospheric clouds. The aerosol impact on cloud retrievals was studied for the volcanoes Kasatochi (August 2008), Sarychev Peak (June 2009), and Nabro (June 2011). Long-lasting aerosol scattering is detected after these events in the Northern Hemisphere for heights above $12.5 \mathrm{~km}$ in tropical and polar latitudes. Aerosol top heights up to about $22 \mathrm{~km}$ are found in 2009 and the enhanced lower stratospheric aerosol layer persisted for about 7 months. In August 2009 about $82 \%$ of the lower stratosphere between 30 and $70^{\circ} \mathrm{N}$ was filled with scattering particles and nearly $50 \%$ in October 2008. 


\section{Introduction}

Clouds are extremely variable in form and size in the Earth's atmosphere. Thus the physical cloud parameters, for example the optical thickness, albedo, and the bottom/top heights from near the ground up to the tropopause, are highly variable. Clouds cover about $66 \%$ of the Earth. The value depends on the used optical thickness threshold (Stubenrauch et al., 2013). Clouds are composed of liquid particles $(T>$ $\left.0^{\circ} \mathrm{C}\right)$, ice $\left(T \approx<-38^{\circ} \mathrm{C}\right)$, or a mixed phase for intermediate temperatures (Boucher et al., 2013).

Clouds also impact the Earth's radiative balance and play a major, yet still relatively uncertain, role in the changing energy budget (IPCC, 2013). The overall cloud radiative effect depends on cloud type and top height, which is a combination of greenhouse warming (longwave) and reflective cooling (shortwave). The knowledge of global cloud characteristics is essential in different fields of numerical analyses, for instance, weather prediction, circulation, or climate change models.

Optically thick clouds scatter a high percentage of the incoming visible light back to space due to their high albedo. A cloud radiative effect of about $-50 \mathrm{Wm}^{-2}$ is expected due to the enhancement of the annual global albedo. Additionally, clouds absorb and emit infrared (terrestrial) radiation, which strongly depends on cloud temperature. The longwave effect is annually and globally averaged on the order of $30 \mathrm{Wm}^{-2}$ (Boucher et al., 2013). Cloud properties and their development in a changing climate will determine the net effect.

The light scattering ability of cloud droplets in the visible and near infrared is only weakly wavelength dependent in comparison to light scattered by molecules. Furthermore, light inside a cloud will encounter enhanced path lengths as it is scattered multiple times at the water or ice particles inside the cloud, and light absorption by trace gases in the clouds will be enhanced.

Tropical clouds can reach heights of roughly $17 \mathrm{~km}$. Either deep convective clouds or the more common cirrus clouds are observed in the tropical tropopause layer (TTL) above $14 \mathrm{~km}$ (Fueglistaler et al., 2009). Cirrus clouds are mainly formed in the upper troposphere (above $8 \mathrm{~km}$ ) by condensation nuclei such as mineral dust and metallic particles via heterogeneous freezing. Larger biological particles are removed by deposition before reaching these altitudes. Cirrus clouds are either produced by the uplift of humid air or by a convective blowoff from deep convection. They are made of small ice crystals due to the low temperatures at these heights $\left(<-30^{\circ} \mathrm{C}\right)$ (Cziczo et al., 2013).

In $84 \%$ of the measurements of Cloud-Aerosol Lidar and Infrared Pathfinder Satellite Observations (CALIPSO), cirrus layers have a vertical extension of less than $1.5 \mathrm{~km}$ at heights between 13 and $16 \mathrm{~km}$ (Massie et al., 2007). Only $1.5 \%$ of the cirrus are more than $3 \mathrm{~km}$ thick. Cirrus layers near the tropopause can be as thin as $0.5 \mathrm{~km}$ and have a horizontal extent up to a few thousand kilometres as detected by $\mathrm{Li}$ - dar measurements made on the space shuttle (Winker et al., 1998).

Cirrus clouds are categorized as (a) subvisual, i.e. optically very thin with cloud optical depths (COD) $\tau_{\mathrm{N}}<0.03$, (b) thin $\left(0.03<\tau_{\mathrm{N}}<0.3\right)$, or (c) opaque $\left(\tau_{\mathrm{N}}>0.3\right)$ (Sassen and Cho, 1992). Subvisual clouds are mainly found in the tropics with higher occurrence frequencies over oceans and during the night. Thin cirrus clouds are more frequent at night and are found mainly over equatorial land masses and the western Pacific. Moreover, opaque cirrus clouds are mainly found during the day over oceans (Sassen et al., 2009). Cirrus cloud occurrence frequencies (COFs) are also coupled to the dynamic circulation patterns. Davis et al. (2013) reported that TTL thin cirrus COFs are partly driven by the quasi-biennial oscillation (QBO) and the upwelling in the tropical branch of the Brewer-Dobson circulation (BDC). For example, a reduced BDC upwelling and a warm QBO westerly phase increase the TTL temperature and reduce the relative humidity, which in turn leads to a COF reduction.

High-altitude, optically thin clouds are nearly transparent for the incoming shortwave solar radiation, but they partially absorb Earth's outgoing longwave radiation. As the cloud particles are much colder than the surface, they re-emit comparatively less radiation towards space. The net effect is a warming of the atmosphere below the cloud ("cloud greenhouse forcing"). Low clouds $\left(z_{\mathrm{ct}}<3 \mathrm{~km}\right)$, however, are the main contributors to an enhancement of the global albedo. Leahy et al. (2012) found that nearly half of all clouds over non-polar oceans have low top heights of $z_{\mathrm{ct}}<3 \mathrm{~km}$. These clouds have an horizontal extent on the order of $2 \mathrm{~km}$. Approximatively $40 \%$ of all clouds are low-level (above $680 \mathrm{hPa}$, below $3.2 \mathrm{~km}$ ), $15 \%$ are mid-level, and $45 \%$ highlevel (below $440 \mathrm{hPa}$, above $6.5 \mathrm{~km}$ ) clouds (IPCC, 2013).

Different methods exist to measure cloud properties from space (Stubenrauch et al., 2013). Nadir-viewing, passive instruments like GOME or SCIAMACHY are specifically designed to derive trace gas columns (Burrows et al., 1995; Bovensmann et al., 1999). However, they can also retrieve cloud top heights (CTHs) using the strongest absorption band of molecular oxygen (i.e. $\mathrm{O}_{2}$ A band: $755-775 \mathrm{~nm}$ ) (Koelemeijer et al., 2002; Rozanov et al., 2004; Lelli et al., 2012) and infer global trends from the concatenation of a measurement record of 17+ years (Lelli et al., 2014). The cloud height accuracy of these methods is within a few hundred metres. However, these retrievals are mostly restricted to cloud optical depths larger than 5. A global COD of $3.9 \pm 0.3$ is retrieved from the International Satellite Cloud Climatology Project (ISCCP) D2 data (Rossow and Schiffer, 1999). Thus not all clouds are detectable from passive nadir observations, like cirrus and cirrostratus clouds with a mean COD of $\tau_{\mathrm{N}}=2.2$ ). These clouds have a global annual mean cloud occurrence frequency of $16.7 \%$ as measured by the Cloud-Aerosol Lidar with Orthogonal Polarization (CALIOP) aboard the CALIPSO satellite (Sassen et al., 2009). 
A number of satellite missions are specially designed for the detection of cloud properties. For example, CALIOP uses the laser wavelengths of 532 and $1064 \mathrm{~nm}$ to measure physical cloud tops with high accuracy of about $60 \mathrm{~m}$ in the troposphere (Winker et al., 2009). Thin clouds with an optical thickness of about 0.01 are still detectable with this technique. Stubenrauch et al. (2013) reported an average global cloud amount of about $68 \%$ for clouds with optical depths higher than 0.1 . This increases to $73 \%$ when also taking the subvisible cirrus clouds into account (Winker et al., 2009; Chepfer et al., 2010).

Optically thin clouds can also be observed by passive sensors in limb or occultation geometry. For instance, the Stratospheric Aerosol Gas Experiment II (SAGE) instrument aboard the NASA Earth Radiation Budget Satellite (Wang et al., 1996) was able to detect very thin clouds with COD $\tau_{\mathrm{N}}>0.03$. SAGE detected a high global cloud amount of $95 \%$ (Stubenrauch et al., 2012). A long light path of about $200 \mathrm{~km}$ around the tangent point increases the number of possible cloud measurements. The Optical Spectrograph and Infrared Imaging System (OSIRIS) on-board Odin is a limbviewing instrument that can accurately measure thin cirrus top heights and COF above $12 \mathrm{~km}$ using the $1530 \mathrm{~nm}$ IR channel (Bourassa et al., 2005) and the optical thickness of subvisual cirrus clouds at $750 \mathrm{~nm}$ (Normand et al., 2013). The High Resolution Dynamics Limb Sounder (HIRDLS) on-board the AURA spacecraft detects cirrus clouds, deep convective clouds, and polar stratospheric clouds (PSCs) using infrared radiances at $12.1 \mu \mathrm{m}$ (Massie et al., 2007). Michelson Interferometer for Passive Atmospheric Sounding (MIPAS) on ENVISAT detected similar cloud parameters using bands in the mid-wavelength infrared and thermal infrared regions (Spang et al., 2012; Sembhi et al., 2012).

Clouds in the instruments' field of view influence the retrieval accuracy of atmospheric trace gas concentrations from limb measurements. The cloud-contaminated part of the measurement profile should be omitted in the retrieval algorithm to minimize trace gas retrieval errors (Sonkaew et al., 2009). As a consequence, we have developed the SCIAMACHY cloud detection algorithm (SCODA). This retrieval scheme uses a colour ratio method to detect cloud top heights in limb-viewing geometry. It was implemented in the SCIAMACHY level 2 operational processor (version 5.04) (ESA, 2013) to improve the limb trace gas retrievals towards the troposphere. It is also used for scientific profile retrievals of upper tropospheric/lower stratospheric water vapour and trace gases like nitrogen dioxide, bromine oxide, and tropospheric ozone (Rozanov et al., 2011; Weigel et al., 2016; Ebojie et al., 2014).

In this study limb observations from the SCIAMACHY spectrometer are used to retrieve cloud top heights using the SCODA colour index ratio approach. We investigate the sensitivity of the method to detect clouds in limb view for different tropospheric cloud types using the radiative transfer model SCIATRAN. We study the latitudinal and seasonal variations of cloud heights. Optically thin clouds throughout the free troposphere were detected and even very thin volcanic aerosol layers in the upper troposphere/lower stratosphere (UT/LS) region. Height-resolved cloud occurrence frequencies are derived from the cloud top height data set to study global cloud field distributions. The method is verified by comparing to other satellite data and literature.

The paper is structured as follows. Section 2 provides information on the data used for this study. The retrieval method to compute cloud top heights from the limb-scattered profiles is described in Sect. 3. The influence of the limb path and the instrument's vertical field of view on the results is analysed in Sect. 3.1. Section 4 presents model simulations performed with the radiative transfer model SCIATRAN to investigate the robustness of the method. SCIAMACHY retrieval results are discussed in Sect. 5. The retrieval method is validated with SCIAMACHY nadir data and MIPAS limb data in Sect. 6. Section 7 explains the influence of volcanic aerosols on retrieval results and conclusions are given in Sect. 8 .

\section{Data}

\subsection{SCIAMACHY}

The atmospheric science instrument SCIAMACHY on board of ESA's ENVISAT is a high-resolution eight channel grating spectrograph (Burrows et al., 1995; Bovensmann et al., 1999). ENVISAT was launched on 1 March 2002 into a polar, sun-synchronous orbit with a mean local Equator crossing time of 10:00 at the descending node. Contact to the satellite was lost on 8 April 2012. The SCIAMACHY instrument covered a spectral range from the UV-C $(214 \mathrm{~nm})$ to the near-infrared IR-B $(2386 \mathrm{~nm})$, with a channel-dependent spectral resolution between 0.22 and $1.48 \mathrm{~nm}$. Scattered, reflected, transmitted, and emitted electromagnetic radiation was observed in solar/lunar occultation, nadir-, and limbviewing geometry. More details can be found in Gottwald and Bovensmann (2011).

\subsubsection{Limb data}

The focus of the SCIAMACHY limb observations are the retrieval of stratospheric $\mathrm{O}_{3}, \mathrm{NO}_{3}$, and $\mathrm{BrO}$ profiles using daytime measurements of scattered solar radiation (see Gottwald and Bovensmann (2011) and references therein). Furthermore, polar stratospheric cloud top heights and stratospheric aerosol extinction profiles are detectable and mesospheric temperatures are retrieved using night-time limb measurements.

Figure 1 gives an impression of the atmosphere from a limb-viewing satellite perspective. The picture was taken from the International Space Station (ISS). Cloud patterns as seen from nadir view are not detectable anymore. Instead we see a strong increase in intensity from space towards the 


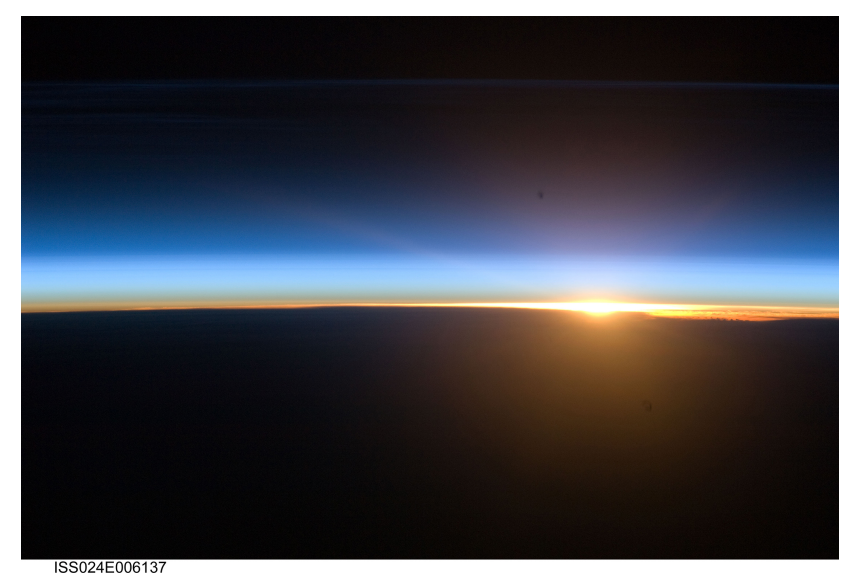

Figure 1. The Earth's limb as seen from the International Space Station on 16 June 2010. The ISS nadir point is in the Aegean Sea at $36.8^{\circ} \mathrm{N}$ latitude and $27.1^{\circ} \mathrm{E}$ longitude. Image courtesy of the Image Science \& Analysis Laboratory, NASA Johnson Space Center, Mission-Roll-Frame ISS024-E-6137 (http://eol.jsc.nasa.gov).

ground and a change of colour near the surface from dark blue to light blue/white, where we expect the influence of clouds.

SCIAMACHY's instantaneous field of view was at the tangent point $2.6 \mathrm{~km}$ (vertical field of view, VFOV) in vertical and $110 \mathrm{~km}$ in horizontal direction (across-track) for the nominal limb-scatter mode. The scanning time of each tangent height was $1.5 \mathrm{~s}$. Typically four distinct measurements were made in across-track direction from west to east. Each measurement had a horizontal resolution of $240 \mathrm{~km}$ due to the scanning speed and integration time (Bovensmann et al., 1999) and a total swath of $960 \mathrm{~km}$. The horizon was scanned in vertical direction from below the ground to about $92 \mathrm{~km}$ tangent height in more than 30 steps that are $3.3 \mathrm{~km}$ apart (Gottwald and Bovensmann, 2011). This measurement cycle is called a limb state. A profile was not fully vertical due to the movement of the satellite and the scanning scheme. The maximum horizontal displacement between all tangent height points within one profile was about $60 \mathrm{~km}$ in the troposphere. The atmosphere was undersampled with a vertical gap of roughly $0.7 \mathrm{~km}$ between two adjacent tangent heights. The along-track horizontal resolution was approximately $410 \mathrm{~km}$ for one VFOV shell. The limb horizontal resolution is analysed in Appendix A. Full coverage of the Earth required 6 days at the Equator with faster coverage towards the polar regions. Figure 2 shows a schematic view of the limb geometry. The red solid line depicts the instruments line of sight (LOS) and the field of view (FOV) as red dotted lines. The blue circles depict the tangent heights for each LOS, which are numbered from the bottom to the tropopause.

We used the SCIAMACHY version $7.04 \mathrm{~W}$ level $1 \mathrm{~b}$ spectra. The level $1 \mathrm{~b}$ data were calibrated without the polarization correction due to known problems in limb geometry (Liebing, 2013). The radiometric calibration was omit-

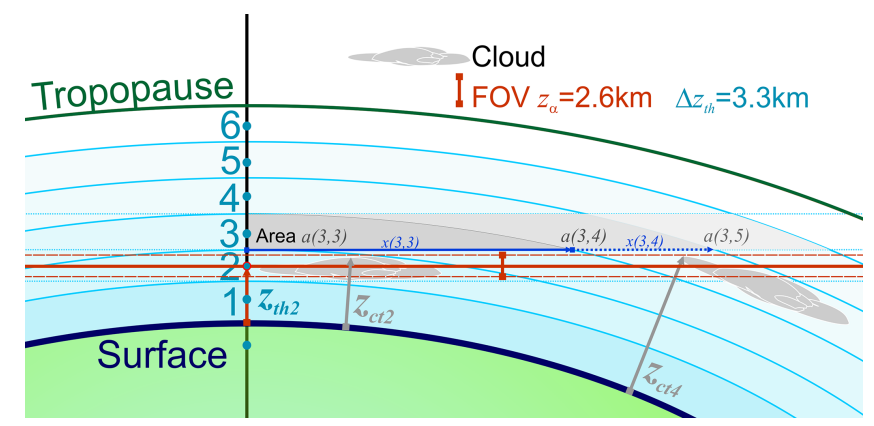

Figure 2. Schematic view of the limb measurement geometry. The shells are numbered from the surface to the tropopause (here 1 to 6). The field of view (FOV), the tangent height step width $\Delta z_{\text {th }}$, and the cloud top height $z_{\mathrm{ct}}$ are superimposed. Examples of shell path lengths $x$ as blue lines and areas $a$ (grey shaded) are shown. The limb path is a combination of the paths through each shell. The sub-paths $x(3,3)$ and $x(3,4)$ (blue line) are depicted belonging to shell 3. The first index stands for the original tangent height and the second index for the current shell of the path segment.

ted as the colour index ratio is a division of two neighbouring tangent height measurements and thus no absolute calibration was needed. Height-resolved limb-scattered spectra were taken from the instrument channels $4(750 \mathrm{~nm})$ and $6 \mathrm{a}$ $(1090 \mathrm{~nm})$. These wavelengths were chosen to avoid molecular absorption bands, e.g. for ozone, oxygen, and water vapour. The retrieval would be disturbed because of the additional absorption features with different height distributions. Radiation at wavelengths below $400 \mathrm{~nm}$ is not suitable because the atmosphere gets optically thick in the upper troposphere due to Rayleigh scattering and ozone absorption increases towards the Hartley-Huggins bands (von Savigny et al., 2005b).

Figure 3 displays the limb radiances $I$ (photons $\mathrm{s}^{-1} \mathrm{~m}^{-2} \mathrm{~nm}^{-1} \mathrm{sr}^{-1}$ ) of channels 4 and 6 as a function of wavelength $\lambda(\mathrm{nm})$ for tangent heights ranging from 2.3 to $22 \mathrm{~km}$. Radiances from channel 5 are not plotted. High intensities are detected for the four lowest tangent heights, where the slope between the retrieval wavelength bands is low. At the tangent height of $15.4 \mathrm{~km}$, the intensities drop significantly compared to $12.1 \mathrm{~km}$ and a steeper gradient between both bands is measured (see black arrows). We conclude that a cloud layer is in the field of view at the lower tangent height. A larger quantity of radiance is scattered into the line of sight. Furthermore, the intensity decreases less with increasing wavelength due to the particle scattering.

\subsubsection{Tangent height knowledge}

The SCIAMACHY tangent heights are not fixed over time and vary up to $400 \mathrm{~m}$ along an orbit. Variations of up to $600 \mathrm{~m}$ are possible within a month. During the early phases of the SCIAMACHY mission the limb tangent height information was erroneous. Differences between the estimated and the 


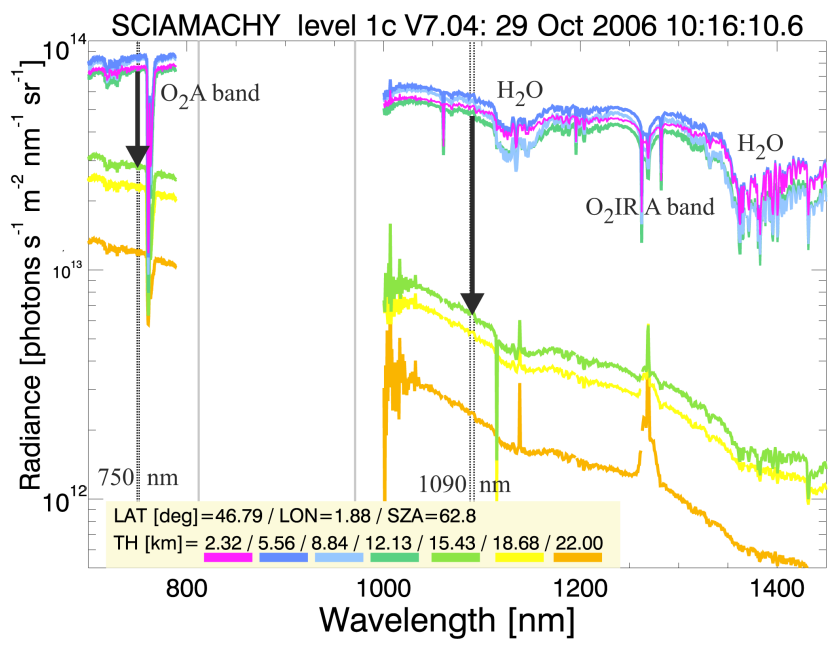

Figure 3. SCIAMACHY limb radiances from channels 4 (700$789 \mathrm{~nm})$ and $6(1000-1300 \mathrm{~nm})$ for tangent heights $(\mathrm{TH})$ from 2.3 (violet) to $22.0 \mathrm{~km}$ (orange). A measurement sequence of the $\mathrm{EN}$ VISAT orbit 24382 (AZM 1) from 29 October 2006 (measurement start time 10:16:10.62 UTC) at $46.8^{\circ}$ latitude, $1.9^{\circ}$ longitude, and $62.8^{\circ}$ sun zenith angle from operational level $1 \mathrm{c}$ data version $7.04 \mathrm{~W}$ (calibration parameters $0-5$ ) has been used. The cloud retrieval wavelength bands around 750 and $1090 \mathrm{~nm}$ are shown as vertical dashed-dotted black lines and the channel borders as grey lines. The largest intensity decrease in both bands is marked by the black arrows.

real tangent height have reached several kilometres (Kaiser et al., 2004; von Savigny et al., 2005a). The main reasons for the tangent height differences are satellite attitude knowledge errors and a misalignment between the SCIAMACHY optical axes and the satellite reference frame, which were later identified and corrected (Gottwald et al., 2007). The geometric tangent height knowledge of the operational level 1 version 7 limb data is now accurate within $170 \mathrm{~m}$ (Gottwald et al., 2010; Bramstedt et al., 2012).

Mean SCIAMACHY limb tangent heights from azimuth index 3 (eastern profile) and the corresponding $2 \sigma$ standard deviations (blue dashed) are calculated from the first measurements of each orbit per day at the beginning of each month (Fig. 4). Superimposed is the difference between two adjacent tangent heights (red line), which is $\approx 3.3 \mathrm{~km}$. At the beginning of the mission in 2003 we detect the largest intra-annual variations when tangent heights varied between $6.8 \mathrm{~km}$ in spring and $4.7 \mathrm{~km}$ at the end of the year. The limb measurement cycle was optimized at this time. The intra-annual amplitude was about $150 \mathrm{~m}$ until the end of the year 2010 with lowest tangent heights at the beginning of each year. In October 2010, the orbital height of the ENVISAT satellite has been lowered by about $17.4 \mathrm{~km}$ to extend the mission lifetime. As a consequence, each limb state was truncated by one tangent height step to maintain the limb/nadir matching (Gottwald and Bovensmann, 2011; Ebojie et al., 2014). The limb tangent height pattern was modi-

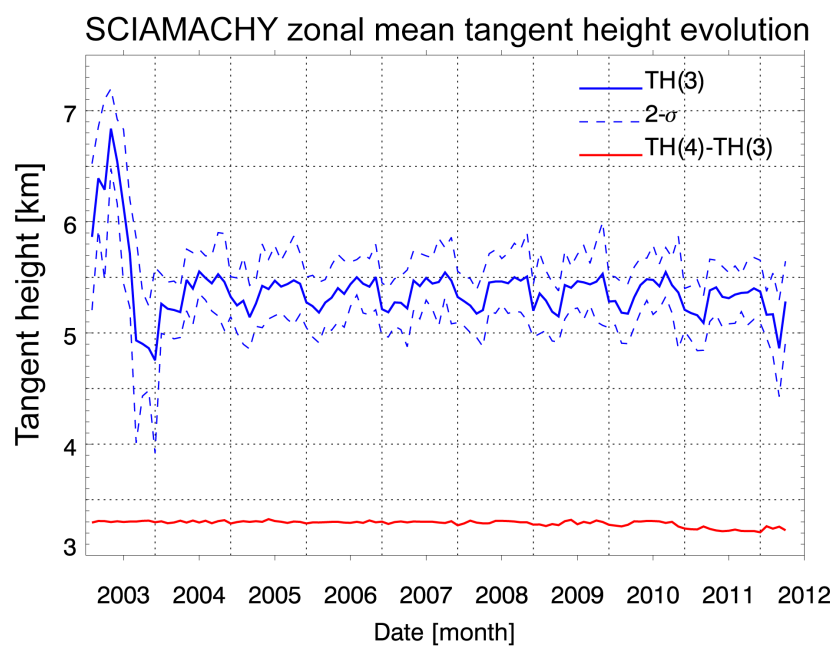

Figure 4. Time series of one limb tangent height (in $\mathrm{km}$ ) covering the SCIAMACHY mission lifetime; e.g. TH(3) is the tangent height with index number 3 . Daily means were plotted, taken from the first state of 10 orbits of 1 day per month (usually the first day). The dashed blue lines depict the corresponding $2 \sigma$ standard deviation. The red line shows the tangent height step width, which is here the difference $\mathrm{TH}(4)-\mathrm{TH}(3)$ between two adjacent tangent heights.

fied again in January 2011 (see also Fig. 4) when tangent heights were lowered by roughly $100 \mathrm{~m}$ and the step width was slightly reduced.

\subsubsection{Nadir data}

SACURA (Rozanov et al., 2004; Kokhanovsky et al., 2005) retrieves the effective radius of cloud droplets, the liquid water path, and other parameters like the optical thickness for optically thick clouds $\left(\tau_{\mathrm{N}} \geq 5\right)$. The cloud top height is determined from spectral measurements in the oxygen A band $(755-770 \mathrm{~nm})$. The total cloud top height error is about $\pm 400 \mathrm{~m}$ for most of the cases (Lelli et al., 2012) (Fig. 1). However, it increases with cloud height and can be up to $1400 \mathrm{~m}$ for high clouds with a low optical thickness. SACURA takes multiple scattering of light inside and below the clouds into account (Lelli, 2013). Therefore, the SACURA model is more accurate than retrieval schemes treating clouds as Lambertian reflectors. Stubenrauch et al. (2012) showed that passive remote sensing techniques tend to detect a "radiometric cloud top height", which can be up to a few kilometres lower than the physical cloud top height. We used SACURA cloud top heights retrieved with SCIAMACHY level 1 version 7.04W data.

\subsection{MIPAS}

The limb sounder MIPAS retrieved vertical temperature profiles, trace gas profiles, and cloud distributions. The Fourier transform infrared spectrometer measured emissions in the mid-infrared ranging from 4150 to $14600 \mathrm{~nm}$ with high spec- 
tral resolution (Fischer et al., 2008). While SCIAMACHY scanned the limb in forward flying direction of the ENVISAT satellite, MIPAS faced backwards. MIPAS had a similar resolution as SCIAMACHY in limb mode along the LOS and in vertical direction $(3 \mathrm{~km})$. However, the resolution perpendicular to the LOS of $30 \mathrm{~km}$ was considerably higher than SCIAMACHY $(240 \mathrm{~km})$. Due to the specific spectral measurement range, MIPAS was able to measure day and night and as a pure limb sounder recorded more limb scans per orbit than SCIAMACHY.

The MIPAS scan measurement time in nominal mode was $56.7 \mathrm{~s}$ with 27 floating altitude grid points from 7 to $72 \mathrm{~km}$ after 2005. After severe in-flight anomalies in 2004, the duty cycle of $100 \%$ was reached again in December 2007. The vertical sampling step size in the UT/LS region was $1.5 \mathrm{~km}$, which led to an oversampling of the atmosphere by a factor of 2. SCIAMACHY instead undersampled the atmosphere. The lowest tangent height was not constant along the orbit. It varied from $5 \mathrm{~km}$ at the poles to $12 \mathrm{~km}$ at the Equator as a function of latitude $\phi$ with $z_{\mathrm{th}}(\phi)=12-7^{*} \cos (90-\operatorname{abs}(\phi))$ (Raspollini and Ceccherini, 2011). Thus only cloud top heights above $8.5 \mathrm{~km}$ were retrieved in the tropics and extratropics $\left(30^{\circ} \mathrm{N} / \mathrm{S}\right)$.

Different methods to detect clouds have been adopted for MIPAS (Spang et al., 2012). Using a cloud index (CI) method (Spang et al., 2002), a fast detection scheme for the operational level 2 processing was developed to omit cloudcontaminated measurements. This method was also used to derive cloud field characteristics like global cloud top distributions and occurrence frequencies (Spang et al., 2005; Sembhi et al., 2012). The standard operational CI approach used two micro windows from 788.2 to $796.2 \mathrm{~cm}^{-1}$ and from 832.0 to $834.4 \mathrm{~cm}^{-1}$ in the MIPAS CI-A band with a fixed threshold (see Spang et al. (2012) and reference therein).

Sembhi et al. (2012) presented an optimized cloud and aerosol detection method for MIPAS in which new seasonal-, latitude-, and altitude-dependent cloud detection thresholds were calculated to maximize the sensitivity to cloud/aerosol particles in the MIPAS field of view. Based on these thresholds, a MIPAS CTH data set was calculated for the entire MIPAS mission. We use this data set from 2008 to 2012 for the study.

\section{Determination of colour index ratios and retrieval of cloud top heights}

SCIAMACHY provides measurements of the limb-scattered light integrated along the line of sight. Choosing only wavelengths where trace gas absorptions and emissions can be neglected, for instance around 750 and $1090 \mathrm{~nm}$, the detected radiation is dominated by the scattering processes of molecules, aerosols, and cloud particles (von Savigny et al., 2005b). Rayleigh theory describes scattering on air molecules, which is strongly wavelength dependent. Scatter- ing on aerosols and cloud particles, however, is only weakly wavelength dependent and can be approximated by Mie theory. Water and ice clouds show similar scattering characteristics for the chosen wavelengths. Only above $1400 \mathrm{~nm}$, the water and ice absorption have different and non-negligible spectral dependencies (Kokhanovsky et al., 2006), which can be used to discriminate phases or to distinguish between cloud and aerosol particle.

Dividing the spectrally averaged radiances of two wavelength bands (750-751, 1088-1092 $\mathrm{nm}$ ) by each other, we can differentiate between measurements where particles are situated in the FOV and those not affected by particles. This is called the colour index approach. Colour is defined here as the ratio between radiances from two different wavelength bands of the same viewing LOS or tangent height. The technique was previously applied to SCIAMACHY limb measurements for the detection of polar stratospheric clouds (von Savigny et al., 2005b) and the determination of the cloud top height of a hurricane cell (Kokhanovsky et al., 2005). This work is a generalization of these previous studies with respect to global particle (cloud) detection and the use of SCIAMACHY tangent heights from the Earth's surface up to $30 \mathrm{~km}$.

The cloud top height $z_{\mathrm{ct}}(\mathrm{km})$ is determined using radiance profiles in different wavelength regions. The heightdependent colour index $\mathrm{CI}\left(z_{\text {th }}\right)$ is first calculated for all tangent heights $z_{\text {th }}[\mathrm{km}]$ from the ratio of two limb-scattered radiance intensities $I$ at different wavelengths $\lambda$ :

$\mathrm{CI}\left(z_{\mathrm{th}}\right)=\frac{I_{\mathrm{h}}\left(z_{\mathrm{th}}, \lambda_{\mathrm{h}}\right)}{I_{1}\left(z_{\mathrm{th}}, \lambda_{1}\right)}$,

where $h$ denotes the high and $l$ the low wavelength band. The radiances are spectrally averaged for the two bands 750 to $751 \mathrm{~nm}$ (l) and 1088 to $1092 \mathrm{~nm}$ (h). The signal-to-noise ratios of SCIAMACHY are roughly 2000 at $15 \mathrm{~km}$ tangent height (Bovensmann et al., 1999) for both the low and the high band, so that noisy spectra have a negligible effect on the retrievals in general. The colour index ratio (CIR) $\Theta[-]$ can then be defined as

$\Theta\left(z_{\text {th }}\right)=\frac{\mathrm{CI}\left(z_{\text {th }}\right)}{\mathrm{CI}\left(z_{\mathrm{th}}+\Delta z_{\mathrm{th}}\right)}$,

where $\Delta z_{\text {th }}$ is the step width between two adjacent tangent heights $z_{\text {th }, i}$ and $z_{\text {th }, i+1}$. The tangent height grid of SCIAMACHY limb observations, for example the spacing between two adjacent altitude levels, is about $3.3 \mathrm{~km}$ wide. This also determines the retrieval accuracy. The step width (Fig. 4, red line) is rather constant throughout the mission lifetime.

The function $\Theta\left(z_{\text {th }}\right)$ peaks at the tangent height where the cloud top $z_{\mathrm{ct}}$ is within the field of view along the line of sight. SCIAMACHY has undersampled the atmosphere in limb view. Cloud tops up to $0.6 \mathrm{~km}$ above the FOV are thus not detectable at the next higher tangent height.

If $\Theta$ exceeds the predefined constant threshold, the cloud top is allocated to that tangent height. A threshold of 1.4 is 


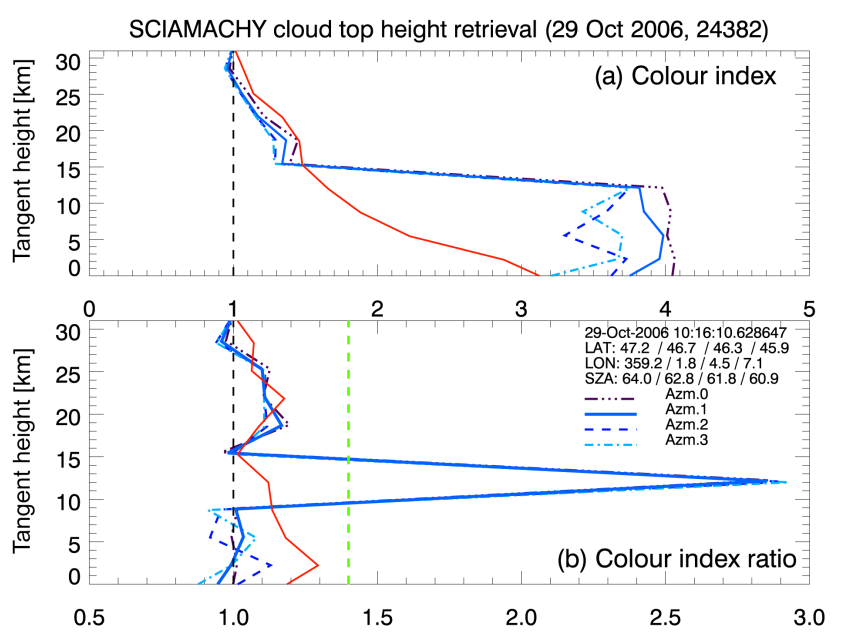

Figure 5. Normalized colour index (a) and colour index ratio (b) of a SCIAMACHY limb state (see Fig. 3) for tangent heights from the ground to $30 \mathrm{~km}$. All four limb profiles (AZM 0-3) are measured simultaneously during a limb state. Superimposed is a cloud-free limb profile (red line) from the same orbit (start time 10:38:59 UTC, AZM 3). The green dashed line depicts the cloud detection threshold.

chosen to reduce false detections due to aerosols in the lower troposphere (see Sect. 4). von Savigny et al. (2005b) used 1.3 for the detection of lower stratospheric PSCs. A radiance calibration is not necessary due to the use of ratios, where all multiplicative and height-independent errors cancel out. However, additive errors such as stray light can still influence the retrieval results (Langowski et al., 2015).

Figure 5 shows the retrieved profiles of (a) the cloud colour index and (b) the colour index ratio for a SCIAMACHY limb state (29 October 2006, 10:16:10.63 UTC) over Europe with four independent profiles in across-track direction of the flight path. For visualization purposes the colour index is normalized by the highest tangent height. A sharp CI decrease at $12 \mathrm{~km}$ is visible for all four measurements. Superimposed is a cloud-free profile (red line) from the same orbit, which exhibits a low surface CI value and a slow decrease with height. Clouds are detected when the CIR $\Theta$ peak exceeds the threshold of 1.4 (dashed green line). Depending on the atmospheric conditions, $\Theta\left(z_{\text {th }}\right)$ is an unknown function of the cloud optical thickness (COT), scattering geometry, albedo, aerosol loading, and signal-to-noise ratio of the measurements. The sensitivity of $\Theta$ to the scattering geometry and optical characteristics will be discussed in Sect. 4.

$\Theta\left(z_{\text {th }}\right)$ can peak more than once in a vertical profile, but only the highest cloud top detected is stored with a corrected quality flag. The double peaks occur in roughly $10 \%$ of all retrievals, suggesting that two or more distinct cloud layers are detected. This happens when, for example, a high thin cloud lies above a low thick cloud. It is not possible to separate the cloud layers when the highest cloud is optically thick. The limb-viewing geometry is not well suited to deal with layered clouds as the position of a cloud along the light path is not known (see also Appendix A).

\subsection{Limb optical thickness}

The main difference between nadir and limb cloud detection is the much larger limb path length and the much coarser horizontal resolution. Long pathways greatly enhance the sensitivity of the limb measurements. However, looking sideways into a cloud field leads to a loss of information on the cloud amount at the tangent point. Thus retrieved cloud occurrence frequencies will in general be much higher than what is detected in nadir geometry. This will be further analysed in Sect. 5 .

The cloud optical thickness $\tau_{\mathrm{L}}$ in limb-viewing geometry is larger than the vertical optical thickness $\tau_{\mathrm{N}}$ due to the long horizontal light path. The path length depends on the instrument's VFOV and the tangent height. For example, an enhancement factor of 226 for the limb optical depth is calculated for a cloud field covering the full VFOV of $1 \mathrm{~km}$ and a top at $15 \mathrm{~km}$ tangent height. Due to the curvature of the atmosphere, a cloud layer drops below the VFOV at a specific point along the line of sight. Taking the area defined by the lines of the VFOV that intersect a shell into account, we calculate an area weighted enhancement factor (AWF) of 151.

This is the highest possible enhancement, because a cloud is not a horizontal layer and will not cover the VFOV completely. The AWF for the SCIAMACHY VFOV of $2.6 \mathrm{~km}$ is 243 . This factor is generally too high. For example, thin cirrus clouds will only fill a part of the VFOV. We simulate this effect by reducing the VFOV to $0.1 \mathrm{~km}$ and then get an $\mathrm{AWF} \approx 47$. This is a more realistic value for the increase of the vertical optical depth in limb geometry.

As a result, a subvisual cloud layer with an optical thickness $\tau_{\mathrm{N}}=0.01$ lying within the field of view of SCIAMACHY has a limb $\tau_{\mathrm{L}}$ of about $2.4(\mathrm{AWF}=243)$ and roughly 0.5 for vertically thin clouds $(\mathrm{AWF}=47)$. In limb view, clouds are detected against the surrounding atmosphere and the background space. The contrast between a cloudy and non-cloudy part of the profile is high compared to a nadir scene. The air pressure above a cloud is lower, less scattering occurs, and the air mass appears darker. The decrease of brightness towards outer space is also visible in Fig. 1. The nadir cloud detection is partly dependent on the contrast at the ground. For instance, ice and snow lead to larger errors in the cloud optical thickness determination (Lelli et al., 2012; Lelli, 2013).

\section{Model simulations}

Simulating radiances in cloudy atmospheres is difficult (Kokhanovsky, 2001) because 1-D radiative transfer models like SCIATRAN (Rozanov et al., 2014) treat clouds only as layers with a defined vertical thickness and general stratified 
Table 1. Pairs of corresponding latitude, longitude, sun zenith angle (SZA), and relative sun azimuth angle (SAA) of one tangent point in SCIAMACHY limb measurement geometry (PN: polar north, MN: midlatitude north, ETN: extra-tropical north, TRO: tropics, MS: midlatitude south, PS: polar south, ETS: extra-tropical south). A measurement from ENVISAT orbit 24381 from 29 October 2006 for the (western) azimuth index 0 is taken for this example.

\begin{tabular}{lrrrr}
\hline Area & $\begin{array}{r}\text { Latitude } \\
\left({ }^{\circ}\right)\end{array}$ & $\begin{array}{r}\text { Longitude } \\
\left({ }^{\circ}\right)\end{array}$ & $\begin{array}{r}\text { SZA } \\
\left({ }^{\circ}\right)\end{array}$ & $\begin{array}{r}\text { SAA } \\
\left({ }^{\circ}\right)\end{array}$ \\
\hline PN & 69 & 35 & 83 & 35 \\
MN & 51 & 26 & 67 & 39 \\
ETN & 37 & 21 & 55 & 46 \\
TRO & -7 & 12 & 32 & 94 \\
ETS & -37 & 4 & 41 & 137 \\
MS & -51 & 357 & 51 & 148 \\
PS & -71 & 334 & 69 & 156 \\
\hline
\end{tabular}

physical properties (optical thickness, effective radius of particles, phase function, cloud phase). This is of course a strong simplification of the complex 3-D structure of a cloud, which cannot be resolved with these kind of models.

The software package SCIATRAN version 3.1 .28 (Rozanov et al., 2014) is used to study the strengths and limitations of the fast and simple CIR retrieval method. The CIR sensitivity is tested for typical atmospheric cloud scenarios like low optically thick or high subvisible clouds. Therefore the influence of cloud parameters (for example, optical thickness $\tau$, top height, layer thickness) and geolocation (sun zenith angle, sun azimuth angle) on the colour index ratio is investigated. The forward model includes a cloud model and has been described and validated by Rozanov et al. (2014). The radiance accuracy is generally better than $1 \%$ compared to other radiative transfer models.

ENVISAT moved from the north to south along the orbit on the day side, with varying sun zenith angle (SZA) and relative sun azimuth angle (SAA) combinations at the limb tangent point. Because of the sun-synchronous orbit with a descending node crossing time of 10:00, only certain combinations of these parameters were possible. The largest sun zenith angles were found near the poles and minima in the tropics (about $26^{\circ}$ ). The relative azimuth angle was generally lower towards the northern high latitudes (SAA about $22^{\circ}$ ) and largest at southern high latitudes (SAA about $157^{\circ}$ ).

Light scattering on aerosols and cloud particles is largest in the north due to stronger forward scattering at low azimuth angles. Minimum scattering occurs in tropical regions for SAAs around $90^{\circ}$. Table 1 shows typical combinations of the SCIAMACHY limb measurement geometry for different latitudes of orbit 24381 from 29 October 2006.

The following parameters are chosen for the tests of CIR sensitivity in a cloudy atmosphere for different cloud top/bottom heights, optical thickness, and geometry. A spherical atmosphere with refraction is modelled with the radia- tive transfer model SCIATRAN (Rozanov et al., 2014). The scalar discrete ordinate technique is used to solve the radiative transfer equation, where absorption of the trace gases $\mathrm{O}_{3}$, $\mathrm{NO}_{2}$, and $\mathrm{SO}_{2}$ is taken into account. The surface is modelled as a Lambertian reflector with a constant albedo $a_{s}=0.1$, which is roughly twice as high as the albedo of water surfaces. The tangent heights are placed from 0 to $30 \mathrm{~km}$ with a step width of $3 \mathrm{~km}$. Radiances are modelled for the wavelengths 750.0 to $751.0 \mathrm{~nm}$ with $0.2 \mathrm{~nm}$ step width and 1088.0 to $1092.0 \mathrm{~nm}$ with $0.8 \mathrm{~nm}$ step width, corresponding to the SCIAMACHY channels 4 and 6 . The SZA varies between 20 and $82^{\circ}$ and the SAA between 20 and $160^{\circ}$ to cover the range of values of the SCIAMACHY limb measurements (see Table 1).

We simulated limb radiances for four typical cloud scenarios to find the limitations of the cloud retrieval method with respect to cloud height and optical thickness. The maximum colour index ratios for one retrieval height are shown as function of sun azimuth and sun zenith angles in Fig. 6. Two water cloud layers with (a) the vertical extents of $2-3 \mathrm{~km}$ (lowest cloud case) and (b) 5-6 km (general water cloud case) are modelled. The spectrally dependent optical thicknesses are $\tau_{\mathrm{N}, \mathrm{wc}}=10.0$ and 0.1 at $500 \mathrm{~nm}$ respectively. Two cirrus cloud layers made of hexagonal ice crystals with $100 \mu \mathrm{m}$ height and $50 \mu \mathrm{m}$ side length (Rozanov et al., 2014) are simulated. We assume (c) an optical thickness $\tau_{\mathrm{N}, \mathrm{ic}}=1.0$ for the layer $8-10 \mathrm{~km}$ (general ice cloud case) and (d) 0.01 for 14$15 \mathrm{~km}$ (subvisual ice cloud case).

The value of CIR is mainly driven by geometry, retrieval height, and cloud and aerosol optical thickness. Thus, we choose combinations of rather low COTs and high aerosol optical thicknesses (AOTs) for all cases except (a). The effective radius of the water droplets is $10 \mu \mathrm{m}$ (Rozanov et al., 2014), which is in the range of values from literature (Rossow and Schiffer, 1999). The particle size has a negligible effect on the CIR of less than $1 \%$ when varying, for instance, the water droplet size between 10 and $50 \mu \mathrm{m}$. In general, ice crystals can vary substantially in size from about 10 to $2000 \mu \mathrm{m}$ and exhibit a variety of different shapes (Liou, 2005). However, the CIR is not sensitive to the size of the ice crystals. The CIR varies by less than $1 \%$ when the crystal size is doubled.

The influence of aerosol contamination on the cloud retrieval is taken into account for all cases. We use the LOWTRAN aerosol parametrization defining the heightdependent extinction coefficient and single scattering albedo. The aerosol optical thicknesses at $790 \mathrm{~nm}$ are chosen to be in range with global means over water and land from measurements of MODIS (Moderate Resolution Imaging Spectroradiometer). MODIS measured regional annual means between 0.04 and 0.34 at $550 \mathrm{~nm}$ (Remer et al., 2008). We selected three AOTs $\tau_{\mathrm{N}, \mathrm{a}}=0.07$ (clean case a), 0.14 (oceanic case bd), and 0.25 (polluted land case c) at $790 \mathrm{~nm}$, which is in the range of global long-term mean values (see Boucher et al., 2013, Fig. 7.14). The aerosol phase functions are calcu- 


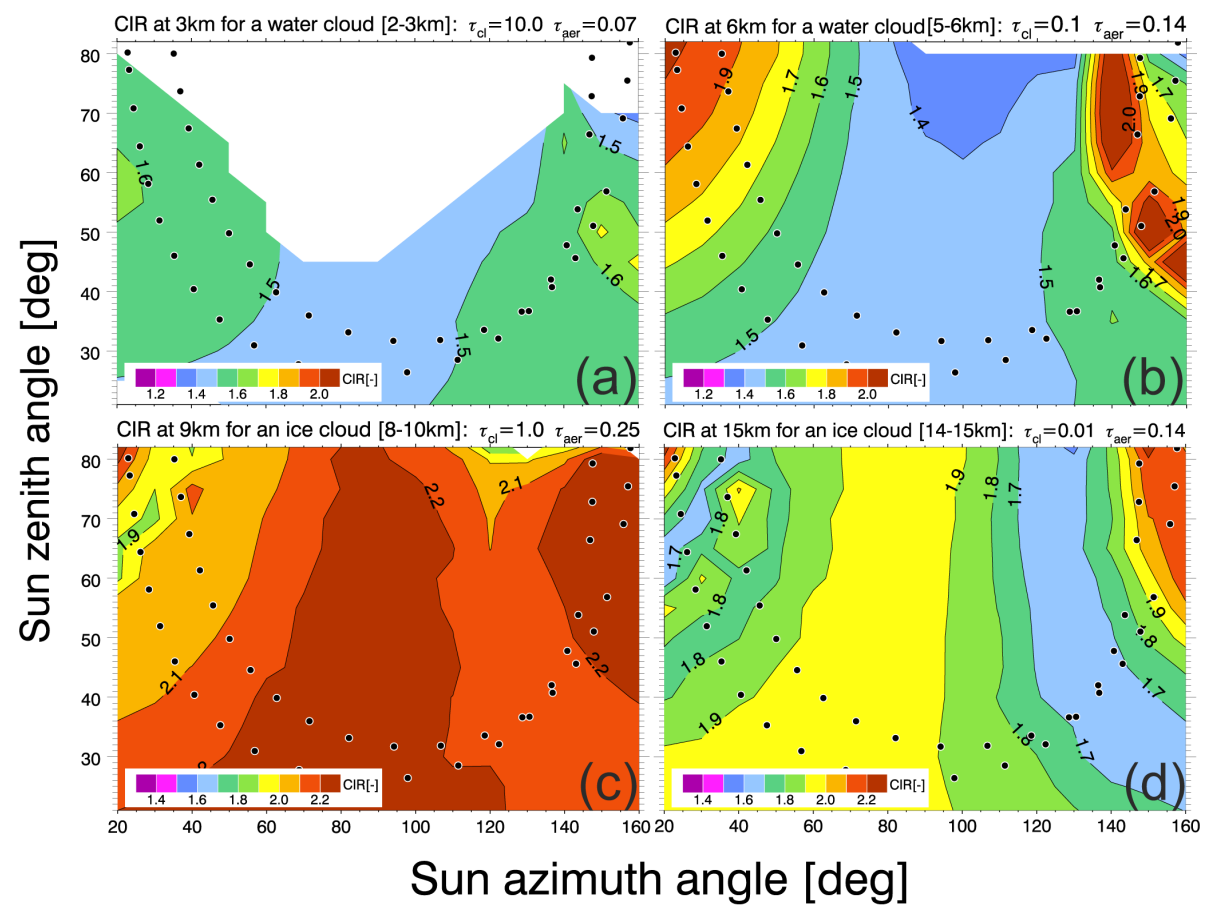

Figure 6. Simulated colour index ratios as a function of sun zenith angle and sun azimuth angle for different cloud layer heights. The radiances are calculated using the SCIATRAN forward model. The CIR are retrieved on a $3 \mathrm{~km}$ height grid. The black and white dots depict zenith and azimuth angle pairs for a typical SCIAMACHY orbit. Small azimuth angles correspond to the Northern Hemisphere and large values to the Southern Hemisphere. Please note the different colour scales for water and ice clouds.

lated using the single parameter Henyey-Greenstein analytical formula with an asymmetry factor of $0.772(0.0-4.0 \mathrm{~km})$, $0.669(4.0-10.0 \mathrm{~km})$, and 0.657 (above $10.0 \mathrm{~km})$ (Rozanov et al., 2014). The AOT defined at $790 \mathrm{~nm}$ corresponds to a larger AOT at $550 \mathrm{~nm}$. For example, $\tau_{\mathrm{N}, \mathrm{a}}=0.25$ at $790 \mathrm{~nm}$ is roughly equal to 0.4 at $550 \mathrm{~nm}$.

The step size for the calculations is $5^{\circ}$ in SZA and $10^{\circ}$ in SAA direction. The black dots depict tangent point SAA/SZA combinations along a typical SCIAMACHY orbit for the west and east profiles with azimuth angle index 0 and 3. Cloud tops are in general detectable for all SZA/SAA pairs for a CIR threshold of 1.4. When the retrieved cloud height differs from the simulated one, the CIR is not plotted (white areas).

In panel (a) we simulate a low, thick water cloud $(2-3 \mathrm{~km}$, $\left.\tau_{\mathrm{N}, \mathrm{wc}}=10.0\right)$ in a clean area $\left(\tau_{\mathrm{N}, \mathrm{a}}=0.07\right)$, which is found mostly over the oceans (Remer et al., 2008). Cloud tops are detected at $3 \mathrm{~km}$ tangent height for most of the geometry combinations except for high SZA. If the modelled aerosol loading is set to the global oceanic mean of 0.14, CTHs at $3 \mathrm{~km}$ would not be detectable anymore. Because most of the aerosol particles are in the lower layer with an optical depth of roughly 0.125 between the ground and $5 \mathrm{~km}$, the CIR is reduced and the retrieved $\mathrm{CTH}$ shifted to the next retrieval tangent height of $6 \mathrm{~km}$.
Low CIR values near the threshold are calculated in sideways (tropics) and backward direction (southern high latitudes) of the scattered light beam (panel b). The cloud is between 4 and $5 \mathrm{~km}$ with low COT $\tau_{\mathrm{N}, \text { ic }}=0.1$ and an oceanic global mean $\tau_{\mathrm{N}, \mathrm{a}}=0.14$. High CIR values are found where the water droplet phase function has a peak in forward direction. The CIR of a simulated cloud increases when the cloud is shifted upwards in the model. Thus the threshold is mainly chosen to sort out wrong cloud top heights due to high aerosol loadings in the lower altitudes. Cloud tops are correctly retrieved above $5 \mathrm{~km}$ for moderate AOT $\tau_{\mathrm{N}, \mathrm{a}} \leq 0.14$. Clouds at the lowest possible SCIAMACHY tangent height between 2 and $3 \mathrm{~km}$ are only retrievable for very low aerosol loading $\left(\tau_{\mathrm{N}, \mathrm{a}} \leq 0.07\right)$. The lowest AOTs are found in clean areas over oceans, especially in the Southern Hemisphere.

Cloud tops consist of ice or mixed phase particles at heights above $6 \mathrm{~km}$ (Mülmenstädt et al., 2015). Thus only ice particle clouds are simulated in the upper troposphere. A CIR map for an ice cloud at $8-10 \mathrm{~km}$ and $\tau_{\mathrm{N}, \mathrm{ic}}=1.0$ over polluted land $\left(\tau_{\mathrm{N}, \mathrm{a}}=0.25\right)$ is shown in panel (c). The retrieved CIR is well above the threshold for all cases. High, subvisible ice clouds $\left(14-15 \mathrm{~km}, \tau_{\mathrm{N}, \mathrm{ic}}=0.01, \tau_{\mathrm{N}, \mathrm{a}}=0.14\right)$ are always detectable with the CIR method (d). Ice and water phase functions differ in complexity and asymmetry (see Rozanov et al., 2014, Fig. 9). Thus we retrieve a more asymmetric SAA dependence for the ice CIR with lowest values around $140^{\circ}$. 
The water phase function has a relatively broad minimum around $100^{\circ}$. This explains the CIR difference for water (a, b) and ice (c, d) particles between 60 and $120^{\circ}$, where CIR is more sensitive to ice particles. High CIRs are found for large SAA/SZA values, making the method also very sensitive to polar stratospheric clouds as already shown by von Savigny et al. (2005b).

The strong CIR dependence on tangent height is already observable in Fig. 6 (Fig. S1 in the Supplement). For instance, the retrieved CIR nearly doubles from about 1.6 $(\mathrm{TH}=5 \mathrm{~km})$ to $3.1(\mathrm{TH}=18 \mathrm{~km})$ when moving a water cloud $\left(\tau_{\mathrm{N}, \mathrm{wc}}=1.0\right)$ with a vertical thickness of $1 \mathrm{~km}$ through the troposphere. The retrieval sensitivity is high enough at lower tangent heights. Under normal aerosol conditions (AOT $<0.14$ ) clouds are detectable for COTs $\tau_{\mathrm{N}, \mathrm{wc}} \geq 0.1$ at $6 \mathrm{~km}$ retrieval height and $\tau_{\mathrm{N} \text {,wc }} \geq 0.005$ in the upper troposphere at $15 \mathrm{~km}$. Sub-visible ice clouds in the upper troposphere are already detectable for cloud optical thicknesses $\tau_{\mathrm{N}, \mathrm{ic}} \geq 0.003\left(\mathrm{SZA}=25^{\circ}, \mathrm{SAA}=83^{\circ}\right.$, cloud layer $15-16 \mathrm{~km})$. The influence of background aerosols and refractive tangent height changes are negligible at these heights. However, the cloud retrieval can occasionally be obstructed by enhanced levels of aerosols from volcanic activity in the upper troposphere when optical thicknesses of clouds and aerosols have the same order of magnitude. The COT limits have been calculated for a spherical shell cloud layer and have to be interpreted as theoretical lower limits. In reality, we expect lower CIR values for very thin cirrus cloud fields that have limited vertical and horizontal extents.

The SCIAMACHY level 1C tangent heights are geometric ones where refraction is not taken into account. The real tangent height is lowered due to atmospheric refraction. The effect is negligible above $22 \mathrm{~km}$, where differences between geometric and refracted tangent heights are less than $100 \mathrm{~m}$. However, the light path at $z_{\text {th }}=6 \mathrm{~km}$ has a refracted tangent height of about $4.9 \mathrm{~km}$. Furthermore, the vertical field of view increases. For the geometric VFOV, we calculate the lower edge at $4.7 \mathrm{~km}$ and the upper edge at $7.3 \mathrm{~km}$. The corresponding refracted VFOV edges are 3.4 and $6.4 \mathrm{~km}$ respectively. The refractive VFOV is thus about $3 \mathrm{~km}$ wide. The lower VFOV edge at the geometric tangent height $2.3 \mathrm{~km}$ above the ground already is below the surface. Thus it is possible to detect clouds down to the Earth's sea surface. However, the colour index ratio at the lowest heights is already near the threshold and the CIR is very sensitive to aerosol contaminations, which increase towards the surface.

\section{Retrieval results}

SCIATRAN was already used for cloud sensitivity studies on the limb ozone retrieval. Sonkaew et al. (2009) concluded that only tangent heights above the cloud top should be used for ozone profile retrievals in order to reduce ozone retrieval errors. The same limb measurement mode was used here to derive cloud top heights in order to minimize differences in time and geolocation with respect to trace gas profile retrievals. The cloud top height retrieval model SCODA was developed and then implemented in October 2010 into the SCIAMACHY level 2 version 5 operational processor (ESA, 2013) to support the retrieval of trace gas profiles in limb view.

SCODA retrieval results are presented in this chapter. We calculated annual means of cloud top heights and heightdependent occurrence frequencies for the troposphere. The limb COF is defined as the number of measurements flagged as cloudy within one grid cell and atmospheric layer divided by the number of all measurements for that grid cell.

\subsection{Annually averaged cloud top heights and occurrence frequencies}

Figure $7 \mathrm{a}$ shows the annual mean cloud top height $(\mathrm{km})$ for 2006. It is calculated by binning the cloudy measurements (roughly 445000 ) on a $2^{\circ} \times 2^{\circ}$ map. Superimposed is the size and horizontal distance of about $780 \mathrm{~km}$ for three SCIAMACHY limb scan cycles or states (red rectangles). Each state is composed of four simultaneous measurements in across-track direction. The approximate footprint size of a limb state is superimposed in panel (b) to a cloud image from SEVIRI (Spinning Enhanced Visible and Infrared Imager) on-board the geostationary Meteosat Second Generation (Schmetz et al., 2002). The lower left corner of the image is at the Equator over the Gulf of Guinea. The fine horizontal structure of a nadir cloud field is not detectable in limb view, because a large air volume is scanned in limb and only the highest cloud tops contribute to the measurement of that volume. Panel (c) shows the corresponding $1 \sigma \mathrm{CTH}$ standard deviation. The largest scatter was found in tropical regions where the high cloud systems have a seasonal variation changing in north/south direction.

The highest cloud tops with heights of about 13 to $16 \mathrm{~km}$ are observed in the tropics. These are typically deep convective and cirrus clouds. The lowest clouds are found in the Southern Hemisphere west of the continents (about $4 \mathrm{~km}$ ). Also a stream of relatively high clouds is detected ranging from the Caribbean Sea over the northern Atlantic Ocean towards northern Europe, which can be related to extra-tropical storm tracks. Similar features are observed east of Japan and in the southern Pacific Ocean towards the west coast of South America. An interhemispheric CTH difference towards the poles is observed that will be further elucidated in Sect. 5.2.

We also observe the interhemispheric difference in the CIR annual average in Fig. 8a. Especially for latitudes greater than $60^{\circ} \mathrm{N} / \mathrm{S}$, the CIR differs by about 0.3 . This is partly due to dependency of the phase function on the scattering angle and thus the latitude, as shown in Sect. 4. Contrarily, stray light, which is an instrumental artefact, has a larger impact on measurements in the high Northern Hemisphere as the sun was shining directly onto the instrument. The SAA 


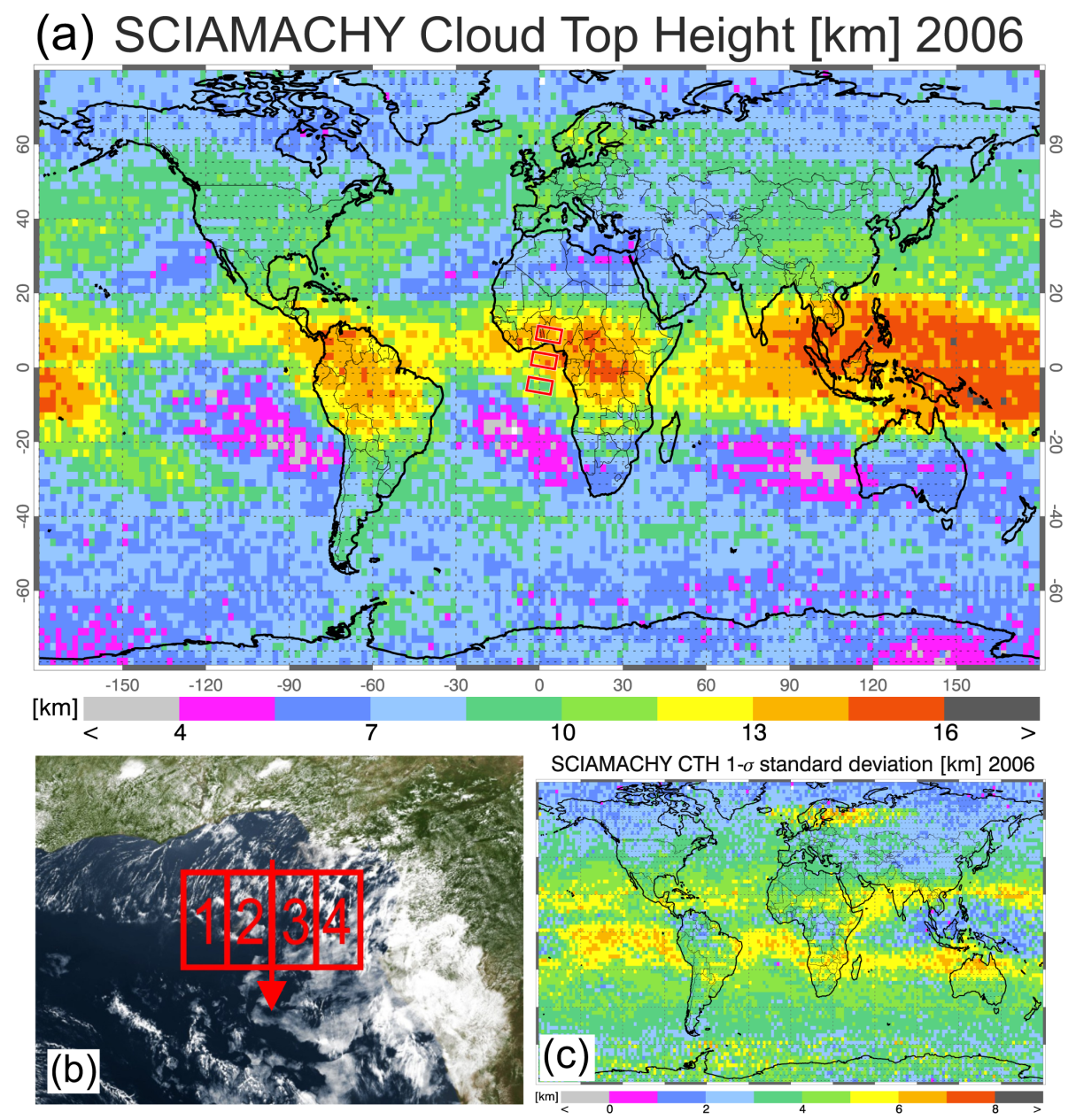

Figure 7. Global map of (a) the annual mean cloud top height (in $\mathrm{km}$ ) for 2006. The data are binned in boxes of $2^{\circ}$ latitude and $2^{\circ}$ longitude. The superimposed red rectangles show the approximate size of three consecutive SCIAMACHY limb scans. The SEVIRI image in (b) shows a part of the African continent near the Equator to illustrate the coverage of a cloud field in limb. It was provided by M. Reuter (Reuter and Pfeifer, 2011). The superimposed red rectangles give the sizes of the four limb measurements of one SCIAMACHY limb scan (limb state) at the tangent point. The arrow indicates the viewing direction. The annual mean CTH standard deviation (in kilometres) for 2006 is shown in $(\mathbf{c})$.

changes from $30^{\circ}(\mathrm{NH})$ to $150^{\circ}(\mathrm{SH})$ at latitudes where $\mathrm{CIR}$ differences are also found in our model studies (see Fig. 6a).

Low CIR regions are furthermore detected in the low cloud top height areas, which is in line with our expectations from model studies. Panel (b) of Fig. 8 shows the SCIAMACHY limb cloud detection rate. A measurement flagged as cloudy is counted when the cloud top height is between 0 and $20 \mathrm{~km}$. Very high values are detected in comparison to cloud occurrence frequencies retrieved in nadir geometry. More than $93 \%$ of the 391700 measurements made in 2006 are marked as cloudy. Cloud-free areas are only rarely detected in SCIAMACHY limb measurements because of the long tropospheric geometric path length of $1200 \mathrm{~km}$. Spang et al. (2012) called it the "limb-smearing effect", which makes comparisons to nadir measurements complicated. Comparatively low cloud detection rates of about $70 \%$ are found only in low cloud top regions, west of the continental coasts in the Southern Hemisphere. The difference between both polar regions already seen in other CTH/CIR maps is also detected here.

A high cloud coverage over desert areas like Australia or North Africa is not expected, but we observed a significantly higher cloud measurement rate, for example, over North Africa in comparison to measurements from high-resolution nadir instruments (see Fig. 12). This can be attributed to measurements of desert dust transported away from these areas up to heights of $6.5 \mathrm{~km}$ (see Fig. 9a-b) and to cirrus clouds at higher altitudes, which are not detectable by passive nadir instruments. Liu et al. (2008) reported consistent high occurrence rates of dust over North Africa and surrounding areas up to altitudes of $6 \mathrm{~km}$. 


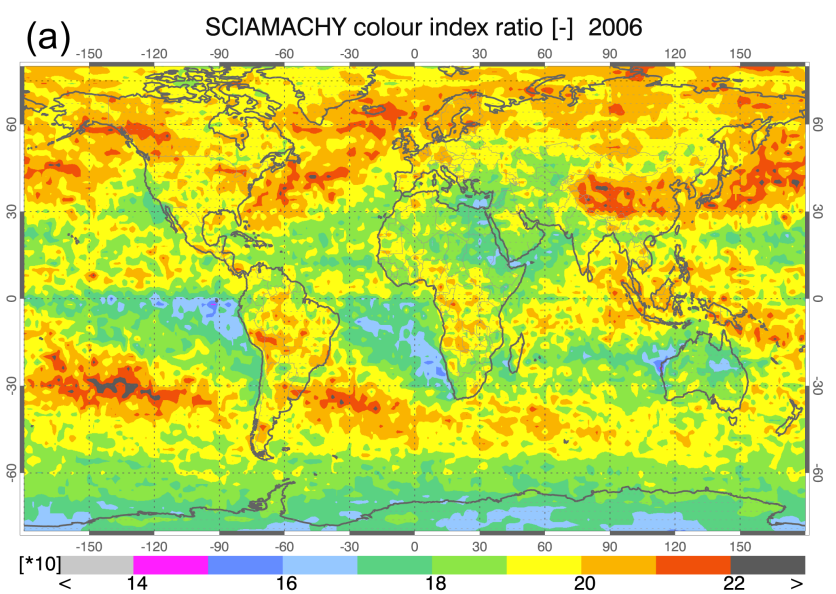

(b) SCIAMACHY mean limb cloud detection rate [\%] 2006

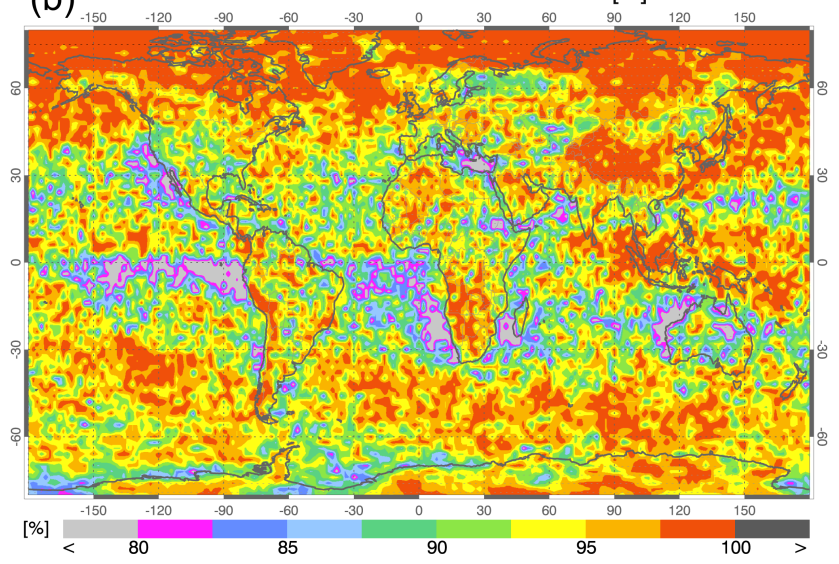

Figure 8. Global annual mean of (a) the maximum colour index ratio and (b) the limb cloud detection rate for 2006. The CIR is multiplied by a factor of 10 .

\subsection{Height-resolved cloud occurrence frequencies}

Figure 9 shows annual mean limb COF (\%) for the year 2006. The COFs are calculated for six altitude layers. Each layer represents a SCIAMACHY tangent height, which was nearly constant over time and orbital position. The COF is calculated by comparing the number of cloud detections in one layer and grid box with the number of all measurements of that grid box.

In layer 1.0-3.75 km (panel a) the largest amount of clouds are detected over oceanic regions in the Southern Hemisphere westwards of the continents. Slightly more clouds are observed between 1.0 and $6.5 \mathrm{~km}$ in the southern polar regions than in the northern counterpart. It seems that the method is rather insensitive to low clouds for small scattering angles and large sun zenith angles, which are typical for high northern latitudes. Stray light might also be a factor that has to be further analysed. Furthermore, the limb-smearing effect can lead to higher retrieved CTHs.

The enhanced COFs over North Africa can be attributed to aerosols uplifted by dust storms over the Sahara, as this region is nearly cloud free. Higher COFs were also detected over the African continent and west of it at the height range $3.75-6.5 \mathrm{~km}$ (b). CALIOP measured dust plumes from Africa up to $8 \mathrm{~km}$ altitude over the Atlantic (Generoso et al., 2008; Liu et al., 2008).

High COF between the midlatitudes and the polar regions were also detected by CALIOP (Chepfer et al., 2010) (see Fig. 3g-h). High COFs at low altitudes $(\mathrm{CTH}<3 \mathrm{~km}$, $>680 \mathrm{hPa}$ ) were mainly found over the oceans, especially near the west coasts of the continents, which is in line with our observations from Fig. 9a. However, CALIOP observed no enhanced COFs over North Africa, supporting the argument that SCIAMACHY detected an aerosol layer in this region.

The largest interhemispheric COF differences are discovered in the layer $6.5-10.0 \mathrm{~km}$ shown in panel (c). The northern hemispheric COF at latitudes north of $60^{\circ} \mathrm{N}$ is above $50 \%$ and in the corresponding Southern Hemisphere on the order of $40 \%$. The combination of COF patterns of layers (a) and (c) explain the interhemispheric CTH differences as seen in Fig. 7. Langowski et al. (2015) observed that the first measurements of the sunlit part in the Northern Hemisphere are influenced by stray light and have to be excluded. For this reason only limb states of the descending orbit phase are used and also the first five states after the descend are omitted.

Cloud tops between 10 and $13.5 \mathrm{~km}$ are mainly detected in areas of frequent storm activities in the extra-tropical zone for latitudes higher than $30^{\circ} \mathrm{N} / \mathrm{S}$ (see Atlas of Extratropical Storm Tracks http://data.giss.nasa.gov/stormtracks/). CALIOP also observed high level clouds above $7.2 \mathrm{~km}$ in these regions (Chepfer et al., 2010) (Fig. 3c-d).

The occurrence of clouds above $13.5 \mathrm{~km}$ is limited to the tropical zone as seen in panels (e) and (f). Largest COFs of about $70 \%$ are detected over the western part of the Pacific from Indonesia to the east between 90 and $180^{\circ}$ longitude. High clouds are also observed over Central Africa and Middle America (above $40 \%$ ). Another feature is the slightly enhanced COF over Antarctica, which can be attributed to PSCs in the southern hemispheric winter/spring period from mid-June to early November.

\subsection{Temporal evolution of CIR and CTH}

The global monthly mean colour index ratio is calculated using all cloud detections for tangent heights between 0 and $25 \mathrm{~km}$. The CIR varies slightly over time (Fig. 10). After a rather stable period from 2003 to 2006 with CIR averages above 2.0, it decreased to 1.84 at the beginning of 2007 and remained around 1.9 until August 2011, when the largest decline down to 1.75 occurred. Some of the short-term CIR reductions corresponded to major volcanic eruptions in 2008, 2009, and 2011. Lower stratospheric volcanic aerosol layers are optically very thin and corresponding CIRs are thus smaller than tropospheric cloud CIRs. 
SCODA limb cloud occurrence frequency 2006

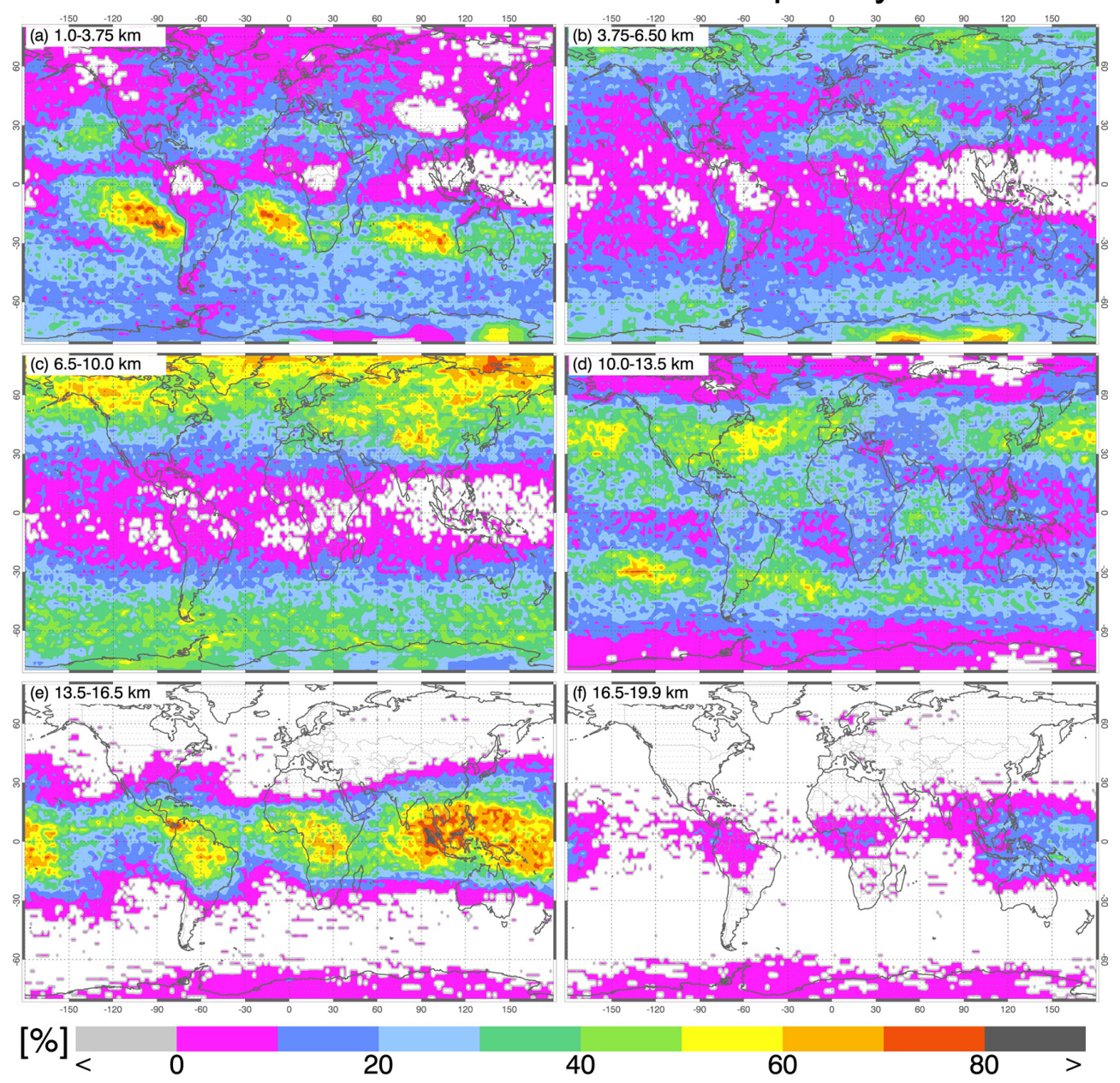

Figure 9. SCIAMACHY annual mean cloud occurrence frequencies for 2006 and for tangent heights between (a) 1.0 and $3.75 \mathrm{~km}$, (b) 3.75 and $6.5 \mathrm{~km}$, (c) 6.5 and $10.0 \mathrm{~km}$, (d) 10.0 and $13.5 \mathrm{~km}$, (e) 13.5 and $16.5 \mathrm{~km}$, and (f) 16.5 and $19.9 \mathrm{~km}$.

Two other wavelength pairs are also tested for their temporal behaviour. Similar features are found for the $1551 / 1090 \mathrm{~nm}$ CIR, which is used in the limb water vapour retrievals as an additional constraint (Weigel et al., 2016). The CIR is also reduced during the longer instrument decontamination phases in August/December 2003, June/December 2004, and December 2008. The $1685 / 1551 \mathrm{~nm}$ CIR is currently under study, which can possibly discriminate between clouds and aerosols. This ratio is rather stable for the whole period, indicating that it is insensitive to aerosols. If the CIR decrease is due to instrumental degradation, it could reduce the detection sensitivity for very thin cirrus and low-altitude clouds because of the constant detection threshold. Nevertheless, the mean CIR is still well above 1.8 at the end of the instruments lifetime in 2012.

Time series of the SCIAMACHY CTH zonal monthly mean for latitudes between $\pm 75^{\circ}$ show an annual cycle and an interhemispheric CTH difference (Fig. 11a). High CTHs are observed in the summer seasons of each hemisphere with generally lower values in the south. Also the maximum CTH is slightly shifted to the north. Highest CTHs above $14 \mathrm{~km}$ are measured near the Equator in the first half of each year and lowest CTHs below $6 \mathrm{~km}$ in the winter periods around $25^{\circ} \mathrm{S}$. PSCs are detected regularly in the southern hemispheric winter with top heights in the lower stratosphere above $12 \mathrm{~km}$. High PSCs in the northern polar region are not clearly detectable in the zonal means but are visible in the standard deviations shown in panel (b). PSCs in the Northern Hemisphere are detected in the winters of 2005, 2007, 2008, and 2011. The four volcano eruptions (red dots) that lead to deviations in cloud top height fields will be analysed in Sect. 7.

There are features both in the CTH and standard deviation maps that cannot be attributed yet. For instance, we observed a considerable increase in CTH between December 2007 and April 2008 around $20^{\circ} \mathrm{N}$ with a large longitudinal scatter taking the standard deviation in panel (b) into account. This might be originating from the volcano 


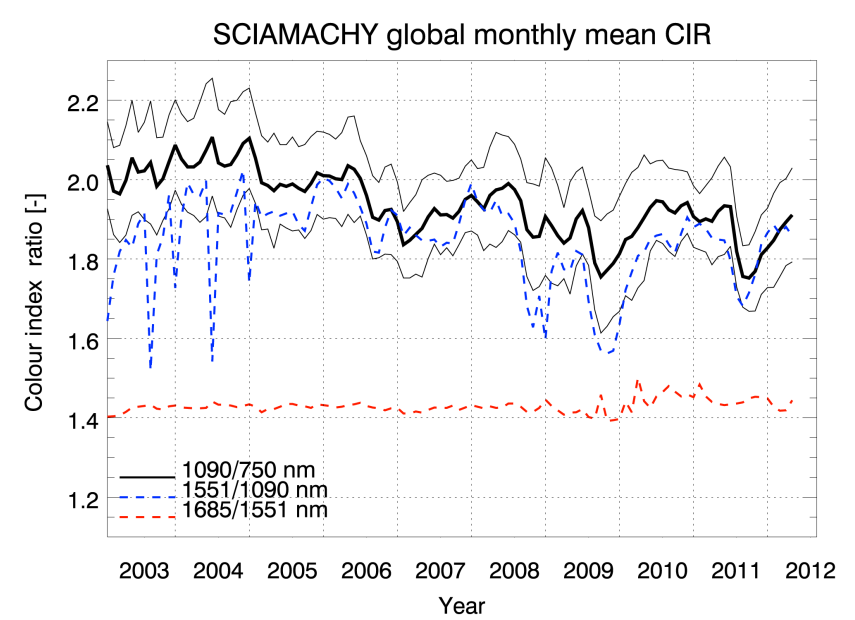

Figure 10. Global monthly averages of the SCIAMACHY colour index ratio CIR for the $1090 / 750 \mathrm{~nm}$ wavelength pair and its $1 \sigma$ standard deviation. Also plotted are two different CIRs using the ratios of 1551/1090 $\mathrm{nm}$ (blue dashed line) and 1685/1551 nm (red dashed line).

Tavurvur $\left(4^{\circ} \mathrm{S}, 152^{\circ} \mathrm{E}\right)$, which erupted between August 2006 and January 2007 with a Volcanic Explosivity Index of 4. Sulfur dioxide and ash clouds reached the tropopause in October 2006 and spread afterwards northwest and southeast (Global Volcanism Program, 2006). However, the largest CTHs and a large longitudinal scatter are observed at the end of 2011 in the latitude band 0 to $10^{\circ} \mathrm{N}$. Mean CTHs up to $21.3 \pm 8.2 \mathrm{~km}$ are detected in December 2011, while normal values are on the order of $13 \pm 4 \mathrm{~km}$ at this location and time of the year. So far the reason for this phenomenon is unclear and has to be further analysed. It might be attributed to rising aerosol particles after the Nabro eruption.

\section{Validation with SCIAMACHY nadir and MIPAS limb cloud top heights}

The comparison of limb measurements with nadir retrieved cloud parameters is no simple task due to long light paths as discussed in Sect. 4 and also addressed by Spang et al. (2012). We first compare cloud top heights retrieved from the two viewing geometries nadir/limb of SCIAMACHY and interpret the differences. We then validate our results with collocated limb CTH from MIPAS in the second subsection.

\subsection{Comparison with SCIAMACHY nadir cloud measurements}

A perfect agreement between limb and nadir cloud top measurements cannot be expected. The two main limiting factors are the low limb horizontal resolution and the high optical thickness threshold necessary for nadir retrievals using passive instruments like SCIAMACHY. We used SACURA data where the following quality checks were applied to

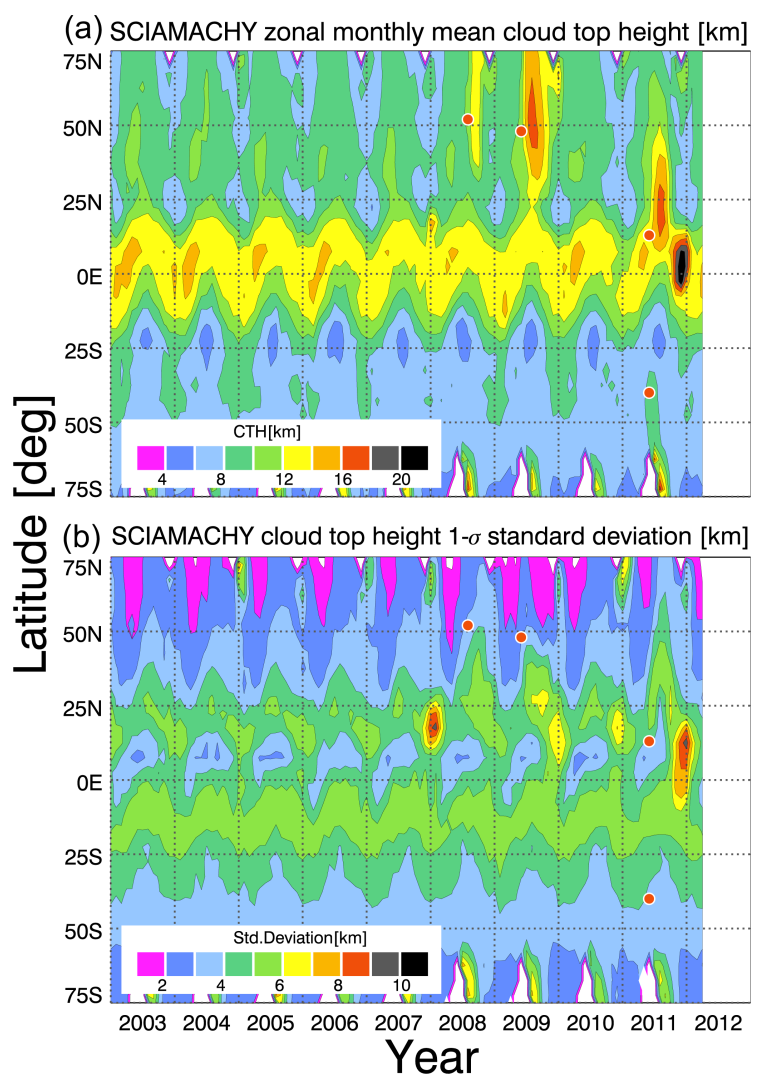

Figure 11. Time series of SCIAMACHY monthly zonal means CTHs (a) and (b) $1 \sigma$ standard deviations (in kilometres) for the period from January 2003 to April 2012 between $75^{\circ} \mathrm{S}$ and $75^{\circ} \mathrm{N}$. The red dots depict the start dates and latitudes of 4 major volcanic eruptions: Kasatochi in August 2008, Sarychev Peak in June 2009, and both Nabro and Puyehue-Cordón Caulle in June 2011.

constrain the nadir data (see Lelli et al. (2012), Table 4): top height convergence (flag 2), top/bottom height convergence (5), high geometrical thickness (3), and a cloud optical thickness larger than 30 .

The mean COFs from nadir SCIAMACHY-SACURA data (Fig. 12) clearly deviate from the limb COF shown in Fig. 9. With the high nadir horizontal resolution a more pronounced land-ocean contrast is detected. The global COF distribution of both viewing geometries above $10 \mathrm{~km}$ altitude is rather similar. A lower percentage of tropical clouds is found in nadir data (panel e-f). Also PSCs in the southern polar region are not detected due to optical thickness limitations. The nadir retrieval is restricted to the detection of clouds with an optical thickness of $\tau_{\mathrm{N}}>5$ (Lelli et al., 2012) and the limb retrieval sensitivity degrades for very low clouds. With a global cloud optical thickness of approximately $3.7 \pm 0.3$ (Rossow and Schiffer, 1999), thin clouds cannot be detected by nadir passive sounders, for instance high-altitude cirrus clouds. This has consequently led to a lower mean top height in the tropics where most of the cirrus clouds are situated. The active nadir-viewing instrument 
SACURA nadir cloud occurrence frequency year 2006

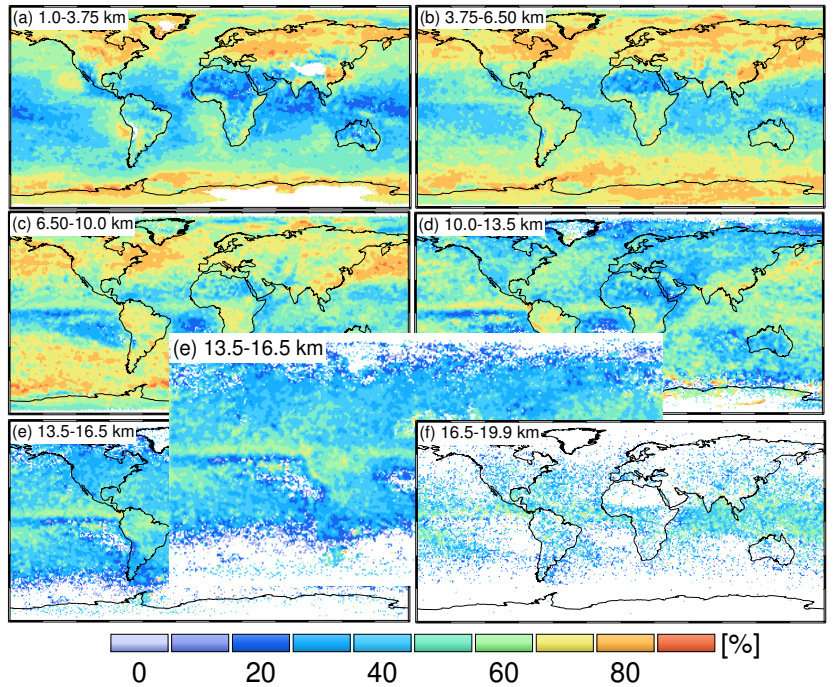

Figure 12. SCIAMACHY SACURA nadir cloud occurrence for the year 2006, projected on a grid of $2^{\circ}$-sided cells. From (a) to (f) values are sorted in altitude layers as in Fig. 9. Due to the inherent conceptual difference between limb and nadir observation geometry, the occurrence is calculated averaging the actual nadir cloud fraction over time, resorting to the ergodic assumption by which space and time averages are equivalent.

CALIOP detected very thin clouds. For instance, $56 \%$ of the total cirrus clouds are observed at subtropical latitudes of $\pm 30^{\circ}$ (Sassen et al., 2009).

The COFs for very low clouds over the oceans are enhanced $(>50 \%)$ in both viewing geometries (a). The limb COF asymmetry between the polar Northern and the Southern hemispheres especially in the lower layer (a) is not observed in nadir view. High nadir COFs are detected in the Northern Hemisphere over land (panel a-b) and over ocean (c). Contrarily, limb COFs are highest between 6.5 and $10 \mathrm{~km}$ north of $60^{\circ} \mathrm{N} / \mathrm{S}$. These high clouds restrain the detection of low clouds in limb view. The enhanced limb COFs over North Africa due to aerosols are not observed in nadir data.

Figure 13 summarizes the latitudinal differences between limb and nadir CTH, where SCIAMACHY zonal mean cloud top heights averaged over 7 years (2003 to 2009) are shown. The black line with the light grey area depicts the SACURA nadir mean $\mathrm{CTH}$ and the $1 \sigma$ scatter. Average CTHs are generally below $10 \mathrm{~km}$ in the tropics and at about $4 \mathrm{~km}$ towards the polar regions. The difference to the SCODA limb averages (orange line) is generally high. Limb CTHs are up to $4.5 \mathrm{~km}$ higher in the tropics near $10^{\circ} \mathrm{N}$. Smaller differences of about $2 \mathrm{~km}$ are observed towards the southern polar region. When the scatter is added to find the highest nadir clouds, we still measure differences of roughly $2 \mathrm{~km}$ in the tropics and of up to $2 \mathrm{~km}$ at latitudes north of $40^{\circ} \mathrm{N}$. The interhemispheric asymmetry is more pronounced in the limb

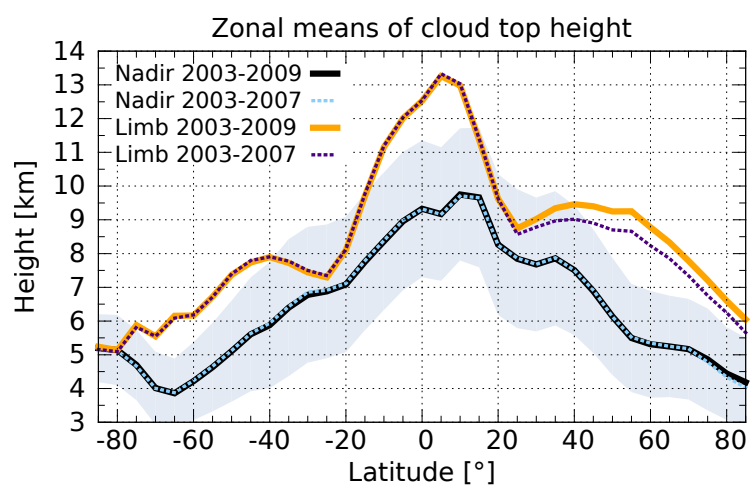

Figure 13. SCODA zonal mean CTH averaged over 5 (2003-2007, violet dashed line) and 7 (2003-2009, orange line) years. The gap in the Northern Hemisphere between both curves shows the influence of the volcanic eruptions in 2008 and 2009 on the retrieval results. The corresponding SACURA nadir zonal means (blue dashed and black line) and the $1 \sigma$ intervals (grey area) are superimposed.

measurements. When the years of high volcanic activity 2008 and 2009 are excluded from the limb average (violet dashed line), the cloud heights in the Northern Hemisphere are only slightly reduced by roughly $0.5 \mathrm{~km}$ in the latitude band from 20 to $82^{\circ} \mathrm{N}$. Mean nadir CTH and standard deviation maps for 2006 are given in Fig. S2.

\subsection{Validation with MIPAS limb cloud top heights}

Better agreement can be achieved with other limb-viewing instruments that have a similar field of view and sensitivity to thin cirrus clouds and aerosol particles (see e.g. Spang et al., 2012; Sembhi et al., 2012). Co-located SCIAMACHY and MIPAS limb measurements of cloud/aerosol top heights are used in this study. The limb tangent point displacement between both sensors is about $170 \mathrm{~km}$ and the temporal displacement is $800 \mathrm{~s}$. The time difference is nearly constant as both instruments looked into opposite directions of the satellite flight path. Both instruments had similar horizontal sampling lengths (Appendix A) due to their VFOVs. A MIPAS validation data set with measurements from January 2008 to March 2012 is used. Because of instrumental problems the resolution of MIPAS was changed in 2005. The full data rate was reached again in December 2007. Hence we have used 2008 as the start year for the comparisons.

Figure 14 shows a scatter plot of SCIAMACHY and MIPAS co-located cloud top heights for April 2010. Only measurements have been used for the comparison when both instruments detected a cloud or particle layer between 8.0 and $22 \mathrm{~km}$. The atmosphere is divided into six latitude bands. The superimposed grey lines depict the SCIAMACHY vertical resolution of about $3.3 \mathrm{~km}$. As MIPAS has a smaller vertical step size and tangent heights are varying continuously over time, MIPAS CTHs cover the whole vertical height range in 


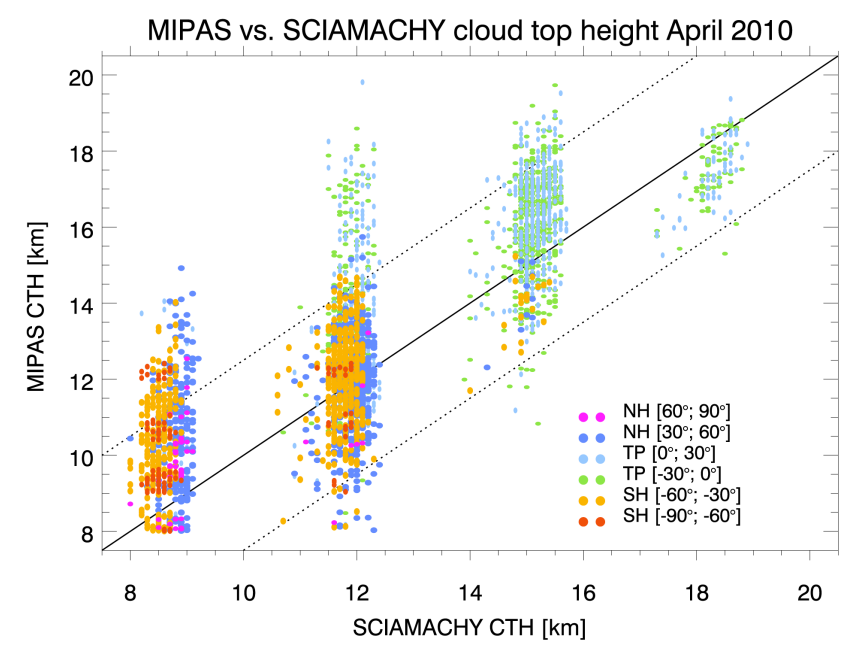

Figure 14. Scatter diagrams of co-located cloud top heights from SCIAMACHY and MIPAS measurements for April 2010. The colour-coded measurement pairs are divided into six latitude bands that are $30^{\circ}$ wide: north/south polar, two midlatitude, and two tropical bands.

contrast to SCIAMACHY, which has a rather fixed tangent height grid.

In general, MIPAS detects cloud tops slightly higher than SCIAMACHY. The monthly mean difference $\triangle \mathrm{SM}=z_{\mathrm{ct}, \mathrm{S}}-$ $z_{\mathrm{ct}, \mathrm{M}}$ for 3121 co-locations is $-0.9 \mathrm{~km}$. For SCIAMACHY CTHs around $9 \mathrm{~km}$, we found a high percentage of MIPAS CTHs that are outside the instruments' vertical field of view. The largest CTH deviations are observed in the tropics (light blue and green dots) where the lowest MIPAS tangent heights are at about $10 \mathrm{~km}$. The main reason seems to be differences in detection sensitivity. MIPAS has a smaller horizontal across-track field of view, which limits the smearing effect to some extent and might lead to a higher sensitivity for very thin clouds. The MIPAS CTH are also expected to be higher by up to $1.0 \mathrm{~km}$ than reality (Sembhi et al., 2012). Furthermore, MIPAS colour indices are affected by water vapour in the troposphere up to $12 \mathrm{~km}$ as reported by Greenhough et al. (2005). These effects can explain why MIPAS has measured consistently higher cloud tops, especially in tropical regions.

Figure 15 summarizes the global CTH differences $\triangle \mathrm{SM}$ of SCIAMACHY and MIPAS. Results are zonally and monthly averaged with vertical differences around $\triangle \mathrm{SM}=-1.1 \mathrm{~km}$. This is in the range of the instrumental field of views that is the limiting factor of the vertical resolution. The differences can partly be attributed to the different tangent height step sizes of $3.3 \mathrm{~km}$ (SCIAMACHY) and $1.5 \mathrm{~km}$ (MIPAS). The largest differences and $1 \sigma$ standard deviations between both data sets are observed at times of volcanic particle intrusions into the UT/LS region (see Fig. S3). Sembhi et al. (2012) compared MIPAS top heights with HIRDLS and CALIOP measurements. They observed that MIPAS CTHs are up to

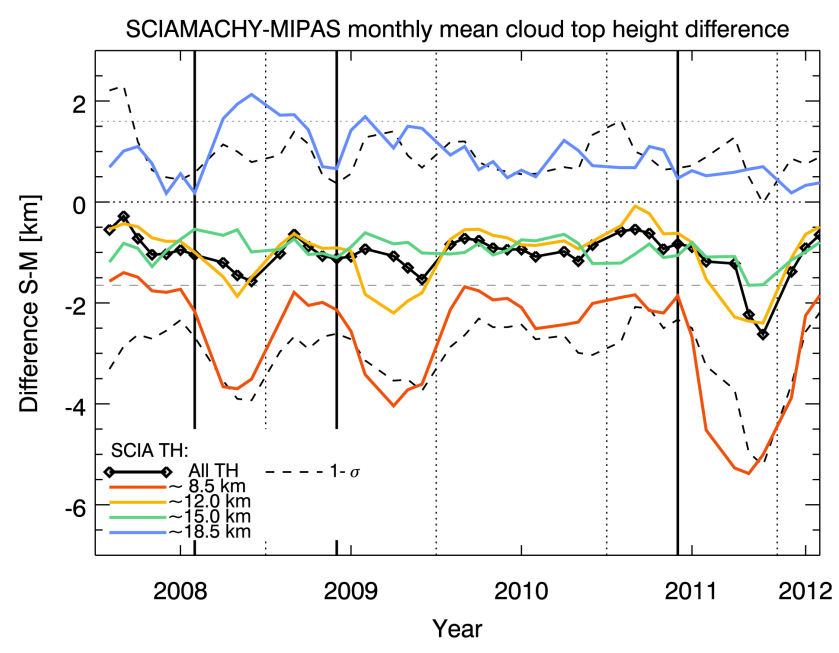

Figure 15. Zonal monthly means of co-located cloud top height differences (in \%) between MIPAS and SCIAMACHY (black line with diamonds) and the corresponding $1 \sigma$ standard deviation (dashed black line) for the time period between 2008 and the end of mission in April 2012. The differences for four SCIAMACHY tangent heights (TH) between 8.5 and $18.5 \mathrm{~km}$ are also shown as coloured lines.

$1 \mathrm{~km}$ higher for altitudes between 12 and $20 \mathrm{~km}$, which is in line with our comparisons.

Taking a closer look at the height-resolved CTH differences, we find the largest discrepancies at the lowest tangent height of about $8.7 \mathrm{~km}$ that is used for the comparison. Here the vertical displacement $\Delta \mathrm{SM}$ for April 2010 is $-1.9 \pm 1.3 \mathrm{~km}$ (415 collocations), $-0.7 \pm 1.7 \mathrm{~km}(1302)$ at $12 \mathrm{~km},-1.1 \pm 1.2 \mathrm{~km}(1071)$ at $15.3 \mathrm{~km}$, and $+0.8 \pm 0.7 \mathrm{~km}$ (128) at $18.5 \mathrm{~km}$. SCIAMACHY cloud top heights are usually higher at the tangent height $18.5 \mathrm{~km}$. This can partially be explained by the coarser tangent height step size and the undersampling of SCIAMACHY, as $18.5 \mathrm{~km}$ is above the tropopause. The largest differences at this height are observed during periods of volcanic aerosol intrusions; for example, the difference is $1.9 \pm 1.2 \mathrm{~km}$ for October 2008 (168 collocations) and $1.7 \pm 1.5 \mathrm{~km}$ for July 2009 (245 collocations). MIPAS is also sensitive to volcanic aerosol particles at heights above $19.5 \mathrm{~km}$, where both instruments detect particles in 2009. However, in this case, the difference of $4.0 \pm 3 \mathrm{~km}$ is much larger than the combined vertical FOVs. This suggests that the instruments have different sensitivities to the small sulfuric acid droplets in the lower stratosphere. The number of co-located measurements in September 2009 at the $18 \mathrm{~km}$ height (514) is more than 10 times higher than in 2010 (64).

In the second half of 2011 both instruments detected high cloud/aerosol layer heights in the tropics (see Fig. 11). Starting in June 2011, the Nabro volcano injected large amounts of sulfur dioxide into the upper troposphere, comparable to the Sarychev peak eruption 2009. While the 
top heights around $18 \mathrm{~km}$ nicely agree $(0.6 \pm 0.8 \mathrm{~km})$ for September 2011, the disagreement at the lowest tangent height is very large $(-5.3 \pm 2.6 \mathrm{~km})$. MIPAS seems to be more sensitive to the Nabro aerosol layer, as the differences between both instruments in the latitude band of $30-60^{\circ} \mathrm{N}$ start to increase after this eruption. The CTH differences increased from $0.7 \mathrm{~km}$ in June 2011 to $5.0 \mathrm{~km}$ in November 2011, which can be attributed to the differences at the lower tangent heights. It has to be noted that the very high CTHs at the end of 2011 as seen in Fig. 11 are only observed in SCIAMACHY data. The high values are restricted to a small latitude band in the tropics. A reason for this event is not found yet.

We also compared zonal mean CTH for heights between 6 and $28 \mathrm{~km}$ with results from Spang et al. (2012) (Fig. 12) (see Fig. S4). The three monthly averages for March-AprilMay and September-October-November 2003 are in relatively good agreement with maximum differences of about $1.5 \mathrm{~km}$.

\section{Particle detection after volcanic eruptions}

The influence of aerosols on the colour index ratio $\Theta$ has already been studied by von Savigny et al. (2005b). High aerosol loading in the upper troposphere/lower stratosphere can lead to false polar stratospheric cloud detection. This is also true for the retrieval of cloud top heights throughout the troposphere.

The lower the cloud, the more an aerosol layer can disturb the retrieval, as the CIR $\Theta$ is strongly height dependent and aerosols tend to reduce the CIR. Aerosols do not exhibit a sharp top height. Because of lower CIR values towards the surface, the extra scattering due to aerosols have a relatively high impact on the CIR. Nevertheless, we detect CTHs at tangent heights below $5 \mathrm{~km}$ mainly in oceanic areas and with a high percentage towards the southern polar regions (see Fig. 9a). As shown in the height-dependent COF distributions, aerosols also influence the detection over desert regions. Furthermore, the intrusion of aerosol particles into the stratosphere is detectable even for very low aerosol optical thicknesses in the UT/LS region, because the threshold $\tau_{\mathrm{N}}$ for subvisual cirrus applies to aerosols as well.

There were three main events during the life cycle of SCIAMACHY, where volcanoes in the Northern Hemisphere ejected a moderate amount of material into the lower stratosphere. The particles are falsely detected as clouds in the lower stratosphere over several months on a semi-global scale. The following eruptions have been observed: Kasatochi $\left(52.1^{\circ} \mathrm{N}, 175.3^{\circ} \mathrm{W}\right)$ starting on $7 \mathrm{Au}-$ gust 2008, Sarychev Peak (Matua Island: $48.1^{\circ} \mathrm{N}, 153.2^{\circ} \mathrm{E}$ ) on 12 June 2009 , and Nabro (Eritrea: $13.4^{\circ} \mathrm{N}, 41.7^{\circ} \mathrm{E}$ ) on 13 June 2011. Mainly for these three events, MIPAS has observed elevated levels of sulfur in the lower stratosphere (Höpfner et al., 2013).
The emitted volcanic sulfur dioxide was transported into the UT/LS region. Over time it was oxidized with water to sulfuric acid and then condensed into larger droplets. The mechanism is slow and takes weeks for the transformation. The sulfuric acid droplets were advected around the globe. Due to the increasing particle diameter, they are detectable in the UT/LS region with the CIR method when the optical depth is high enough.

The EARLINET lidar site found aerosol optical depths at $532 \mathrm{~nm}$ between 0.004 and 0.025 in 2008 for heights above $5 \mathrm{~km}$ (Mattis et al., 2010) and up to 0.07 in 2009 (Kravitz et al., 2011). Mateshvili et al. (2013) measured optical depths up to 0.008 in July 2011 at a wavelength of $780 \mathrm{~nm}$ and aerosol layer top heights of $19 \mathrm{~km}$. OSIRIS measured similar values. Also the aerosol layer was still detectable in the middle of September 2011 (Bourassa et al., 2012). At the same time in June 2011, the Puyehue-Cordón Caulle (PCC) volcano $\left(40.6^{\circ} \mathrm{S}, 72.1^{\circ} \mathrm{W}\right)$ emitted large amounts of mainly ash up to heights of $13 \mathrm{~km}$ (see e.g. the global volcanism program website).

The main components ejected in the Kasatochi and Sarychev event are sulfate (more than $50 \%$ ) and carbonaceous material (less than $43 \%$ ) (Andersson et al., 2013). The percentages changed over time in the UT/LS region and Andersson et al. (2013) estimated a residence time of $45 \pm 22$ days for both volcanoes using measurements from the CARIBIC (Civil Aircraft for Regular Investigation of the atmosphere Based on an Instrument Container) platform. Residence times in the UT/LS region are the longest for aerosols with particle diameters around $1 \mu \mathrm{m}$. A large spread of residence times from 9 to 62 days was reported in other studies (Andersson et al., 2013).

The influence of stratospheric particles on the limb CTH detection is already observable in Fig. 11, where the red dots depict the latitude and estimated start of the breakout from the three volcanoes described above. We now take a closer look at the impact of the three big eruptions and their temporal evolution on the CTH retrieval results. The measurements are sometimes dominated by aerosol particles in the lower stratosphere. Figure 16 shows the impact of volcanic aerosols can be transported into the lower stratosphere at latitudes between 30 and $70^{\circ} \mathrm{N}$. The lowest tangent height layer between 12.5 and $15.5 \mathrm{~km}$ (red line) is situated in the UT/LS region for this latitude band. While the layer is at the upper edge of the troposphere for latitudes near $30^{\circ} \mathrm{N}$, it is already in the stratosphere towards $70^{\circ} \mathrm{N}$. Under normal conditions, the largest occurrence frequencies occur in summer seasons with maxima of nearly $5 \%$ in the lowest layer. The year 2010 is an example of such an undisturbed year in contrast to the other years. Thus only a small amount of particles are observed in the lowest layer, while the two highest layers are completely free of particles for most of the year. Only small areas above $18.8 \mathrm{~km}$ in the wintertime Arctic PSC seasons are filled with particles. 


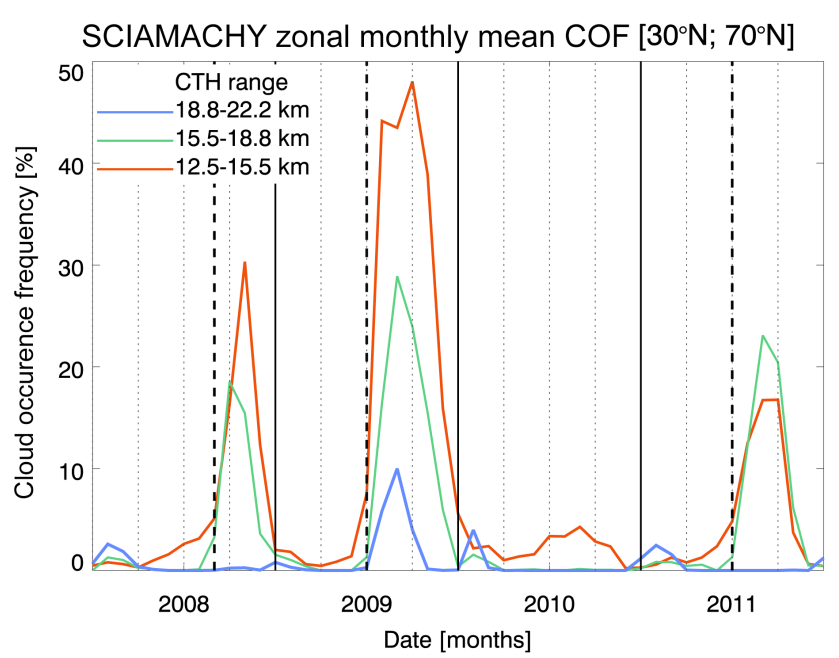

Figure 16. SCIAMACHY monthly zonal mean occurrence frequencies (in \%) of cloud/aerosol scattering layers for the latitude band from 30 to $70^{\circ} \mathrm{N}$ for the years $2008-2011$. Three different cloud top height layers of $12.5-15.5 \mathrm{~km}$ (red line), $15.5-18.8 \mathrm{~km}$ (green), and $18.8-22.2 \mathrm{~km}$ (blue) are depicted. The vertical dashed line show the start months of the three major volcano outbreaks from Kasatochi, Sarychev peak, and Nabro.

Most of the volcanic particles are detected in the layer between 12.5 and $15.5 \mathrm{~km}$. Up to $30 \%$ of the area is covered with aerosols in October 2008. The maximum coverage is about $48 \%$ in September 2009 and $17 \%$ in August/September 2011. The second peak in September 2009 might be due to sedimentation of particles from the layer 15.5 to $18.8 \mathrm{~km}$, where a peak occurrence rate $29 \%$ is seen in August. However, still a considerable amount of aerosols are observed in the intermediate layer with maxima of $19 \%$ in September 2008, $29 \%$ in August 2009, and 23\% in August 2011. A significant occurrence frequency maximum for the layer $18.8-22.2 \mathrm{~km}$ is only observed for September 2009 $(10 \%)$ with lower values in the months before and after September. Overall, about $45 \%$ of all cloud measurements are located in the lower stratosphere in October 2008, $82 \%$ in August 2009, and $40 \%$ in July 2011.

Elevated aerosol levels are observed for about 4 months in 2008, 7 months in 2009, and 5 months in 2011. The time spans for aerosol layer detection in 2008/2009 are in line with measurements from the Infrared Atmospheric Sounding Interferometer of $\mathrm{H}_{2} \mathrm{SO}_{4}$ (Clarisse et al., 2013) and OSIRIS for both volcano eruptions in 2008/2009 (Bourassa et al., 2010; Haywood et al., 2010). Atmospheric Chemistry Experiment Fourier transform spectrometer (ACE-FTS) measurements of $\mathrm{SO}_{2}$ and sulfate aerosols showed a Sarychev particle lifetime of about 7 months (Doeringer et al., 2012). ACE-FTS detected the plume between 8.5 and $17.5 \mathrm{~km}$ with a maximum around $12 \mathrm{~km}$ at higher latitudes $\left(55-70^{\circ} \mathrm{N}\right)$.

While the volcanoes of Kasatochi and Sarychev Peak are at similar latitudes in the Northern Hemisphere, the Nabro volcano is in the tropics and the particles had to be advected into the northern region over time. This might explain why we detect higher amounts (23\%) of particles in the layer 15.5 to $18.8 \mathrm{~km}$ (August 2011) than in the layer below, as particles are already vertically transported into the lower tropical stratosphere, then move northwards, and descend again.

The PCC eruption starting in June 2011 is only barely visible in the time series of Fig. 11 with only a slight increase in mean CTH. However, a similar CIR reduction in the Southern Hemisphere is observed after the eruption as for the other volcanoes. The thin aerosol layers in the UT/LS region lead to lower CIRs compared to clouds and can thus be identified (see Fig. S5).

\section{Conclusions}

In this study, we refined the colour ratio method that was first used for the detection of PSCs in limb-viewing geometry. SCIAMACHY limb measurements were used to investigate the global cloud top height and occurrence distributions for the lifetime of the instrument. The use of only one threshold for all atmospheric situations is simplistic in nature but sufficient for the majority of cases, except for the lowest clouds.

For tangent heights between 2 and $5 \mathrm{~km}$, the influence of aerosols and viewing geometry is not negligible. The retrieved cloud top height can be wrong, because a shift to the next tangent height is possible for moderate aerosol loadings in the troposphere. Nonetheless, we are able to detect low clouds within this altitude range in clean areas, mainly over southern oceans. This is also supported by comparisons with SACURA nadir COF measurements.

SCIATRAN model studies have shown that the method is very sensitive for a wide range of cloud optical properties and cloud top heights. The vertical accuracy of the CTH retrieval is limited to the tangent height step size of about $3.3 \mathrm{~km}$. Also, the spatial resolution is rather coarse. The horizontal field of view can be up to $800 \mathrm{~km}$ along-track and $240 \mathrm{~km}$ across-track, which promotes smearing effects with respect to the location of the cloud field.

Still we found good agreement, comparing our results with co-located MIPAS data. MIPAS has a narrow $30 \mathrm{~km}$ acrosstrack FOV and a tangent height step size of $1.5 \mathrm{~km}$. SCIAMACHY CTHs are usually lower by about $1 \mathrm{~km}$. This can be attributed to differences in the tangent height step size and that MIPAS tends to overestimate the CTH (Sembhi et al., 2012). MIPAS also has an $1 \mathrm{~km}$ offset compared to other satellite measurements (Spang et al., 2012). Furthermore, sensitivity differences of the methods for thin clouds and small aerosol particles lead to larger discrepancies up to $5 \mathrm{~km}$, as seen in the Nabro case in November 2011.

Aerosols affect the CTH retrieval not only at low tangent heights in polluted areas but also after intrusions of larger amounts of volcanic sulfuric acid droplets and ash particles into the UT/LS region. We detected large aerosol- 
contaminated areas for long periods of several months mainly in the Northern Hemisphere in 2008 and 2009. After the Sarychev volcano eruption in 2009 , the northern stratosphere was filled with particles from the poles down to the extra tropics for nearly 7 months. Particles are observed up to heights of about $22 \mathrm{~km}$.

We analysed monthly-sampled cloud top altitudes measured by SCIAMACHY for the two different observational geometries limb/nadir. The CTH differences can partly be attributed to the different sensitivities of the viewing geometries. To this end, a limb/nadir matching technique proves to be advantageous in filling the representation gaps for specific cloud types/regimes, which are only observable in one of both viewing geometries. SCIAMACHY was the only instrument that could simultaneously make use of the two viewing geometries.
The cloud top height detection method first used to detect PSCs was the baseline of the SCODA algorithm. It is now operationally used to improve the operational limb trace gas retrievals towards the tropopause. Here we have shown the importance of the method for cloud and aerosol studies. The use of wavelength pairs in the near IR will possibly enables us to distinguish between clouds and aerosols in the upper troposphere. Scientific studies are currently ongoing. Although SCIAMACHY and MIPAS, with their respective sensitivities, have proven to be of great value for UT/LS studies, new missions with these types of limb-viewing instruments are currently not planned. 


\section{Appendix A: Horizontal Along-Track Resolution}

The along-track horizontal sampling length for one atmospheric shell $2 x(i, i)$ is about $410 \mathrm{~km}$, where $i$ is the index of the tangent height $z_{\text {th }}(i)$ (see Fig. 2). The position of the tropospheric cloud along the line of sight cannot be resolved with the retrieval technique. Thus the real length, where clouds can be sampled, is much longer, as they may also appear in the line of sight outside the lowest shell given by $z_{\text {th }}(i)$. The tropopause is taken as the upper edge for clouds. It is latitude dependent and can reach about $17 \mathrm{~km}$ in the tropics. With this tropopause height (index $i_{\text {tp }}$ ), we calculate the CTH-dependent extra path length. With a cloud top $z_{\text {th }}=6 \mathrm{~km}$ in the tropics, we found a nearly doubled total horizontal sampling length $X=790 \mathrm{~km}$, where clouds can appear along-track within the VFOV. We calculate $X$ as $\sum x\left(i, j=i, \ldots i_{\mathrm{tp}}\right)$. The overall path is $560 \mathrm{~km}$ for a cloud top $z_{\mathrm{ct}}=12 \mathrm{~km}$. For instance, a cloud top $z_{\mathrm{ct}}=3 \mathrm{~km}$, measured over Germany, could be anywhere along the countries north/south axis (about $800 \mathrm{~km}$ ) at altitudes up to the tropopause.

It should be noted that the horizontal sampling length is on the order of the distance between two consecutive SCIAMACHY limb states with a geographic angle of about $7^{\circ}$ $(780 \mathrm{~km})$. For most of the cases, the LOS above a cloud top of one state will not reach the measurement area of the adjacent state, as it is then outside the troposphere already. However, for a LOS from a cloud-free measurement with a tangent point close to the surface, the along-track horizontal resolution is approximately $1200 \mathrm{~km}$, corresponding to an angle of roughly $10^{\circ}$.
To further analyse, whether these long extra paths are relevant for cloud detection, we also have to take the vertical resolution of the instrument into account. We calculate the vertical area-of-sight (VAOS) $a\left(\mathrm{~km}^{2}\right)$, which is defined by a shell segment that is limited in vertical direction by the VFOV. The across-track LOS dimension can be neglected, as it is the same for all VAOS. For example, the path length ratio $x(3,3) / x(3,4)$ is roughly 2.4 and the ratio between the two corresponding areas $a(3,3) / a(3,4)$ is 1.2 (see Fig. 2). The first index defines the tangent height index, the second the index of the shell. All shell areas up to the tropopause are important for the limb cloud detection with area ratios close to 1 .

In trace gas limb retrievals, number densities are calculated for each shell assuming a horizontal continuity in each shell. Thus it is possible to derive trace gas profiles, which can be attributed to the tangent height points. This is not the case for discontinuous cloud fields in our retrieval method. If, for example, the area $a(3,3)$ is free of clouds and $a(3,4)$ is not, the retrieved limb $\mathrm{CTH}$, which is registered at the tangent point, will be higher than the nadir CTH. Furthermore, another cloud in area $a(2,2)$ or $a(2,3)$ is not be detectable in limb. The presence of high clouds outside areas at the tangent point along the light path thus lead to (a) a CTH overestimation and (b) an increase of the cloud occurrence frequency. 


\section{The Supplement related to this article is available online at doi:10.5194/amt-9-793-2016-supplement.}

Acknowledgements. This work was funded in part by ESA within the SCIAMACHY Quality Working Group (SQWG) project and the Sentinel5-Precursor L2 development project (DLR grant 50EE1247). The work was supported by the European Space Agency (ESA), the German Ministry of Education and Research (BMBF), the German aerospace centre (DLR), the University of Bremen and the Ernst Moritz Arndt University of Greifswald, Germany. SCIAMACHY was jointly funded by Germany, the Netherlands, and Belgium.

The article processing charges for this open-access publication were covered by the University of Bremen.

Edited by: G. Stiller

\section{References}

Andersson, S. M., Martinsson, B. G., Friberg, J., Brenninkmeijer, C. A. M., Rauthe-Schöch, A., Hermann, M., van Velthoven, P. F. J., and Zahn, A.: Composition and evolution of volcanic aerosol from eruptions of Kasatochi, Sarychev and Eyjafjallajökull in 2008-2010 based on CARIBIC observations, Atmos. Chem. Phys., 13, 1781-1796, doi:10.5194/acp-13-1781-2013, 2013.

Boucher, O., Randall, D., Artaxo, P. Bretherton, C., Feingold, G.,Forster, P., Kerminen, V.-M., Kondo, Y., Liao, H., Lohmann, U., Rasch, P.,Satheesh, S.K., Sherwood, S., Stevens, B., and Zhang, X.Y.: Clouds and Aerosols, in: Climate Change 2013: The Physical Science Basis. Contribution of Working Group I to the Fifth Assessment Report of the Intergovernmental Panel on Climate Change, edited by: Stocker, T. F., Qin, D., Plattner, G.-K., Tignor, M., Allen, S. K., Boschung, J., Nauels, A., Xia, Y., Bex, V., and Midgley, P. M., Cambridge University Press, Cambridge, United Kingdom and New York, NY, USA, 571658, doi:10.1017/CBO9781107415324.016, 2013.

Bourassa, A. E., Degenstein, D. A., and Llewellyn, E. J.: Climatology of the subvisual cirrus clouds as seen by OSIRIS on Odin, Adv. Space Res., 36, 807-812, doi:10.1016/j.asr.2005.05.045, 2005.

Bourassa, A. E., Degenstein, D. A., Elash, B. J., and Llewellyn, E. J.: Evolution of the stratospheric aerosol enhancement following the eruptions of Okmok and Kasatochi: OdinOSIRIS measurements, J. Geophys. Res.-Atmos., 115, D00L03, doi:10.1029/2009JD013274, 2010.

Bourassa, A. E., Robock, A., Randel, W. J., Deshler, T., Rieger, L. A., Lloyd, N. D., Llewellyn, E. J. T., and Degenstein, D. A.: Large volcanic aerosol load in the stratosphere linked to Asian monsoon transport, Science, 337, 78-81, doi:10.1126/science.1219371, 2012.

Bovensmann, H., Burrows, J. P., Buchwitz, M., Frerick, J., Noël, S., Rozanov, V. V., Chance, K. V., and Goede,
A. P. H.: SCIAMACHY: Mission Objectives and Measurement Modes, J. Atmos. Sci., 56, 127-150, doi:10.1175/15200469(1999)056<0127:SMOAMM>2.0.CO;2, 1999.

Bramstedt, K., Noël, S., Bovensmann, H., Gottwald, M., and Burrows, J. P.: Precise pointing knowledge for SCIAMACHY solar occultation measurements, Atmos. Meas. Tech., 5, 2867-2880, doi:10.5194/amt-5-2867-2012, 2012.

Burrows, J. P., Hölzle, E., Goede, A. P. H., Visser, H., and Fricke, W.: SCIAMACHY - scanning imaging absorption spectrometer for atmospheric chartography, Acta Astronaut., 35, 445-451, doi:10.1016/0094-5765(94)00278-T, 1995.

Chepfer, H., Bony, S., Winker, D., Cesana, G., Dufresne, J. L., Minnis, P., Stubenrauch, C. J., and Zeng, S.: The GCM Oriented CALIPSO Cloud Product (CALIPSO-GOCCP), J. Geophys. Res., 115, D00H16, doi:10.1029/2009JD012251, 2010.

Clarisse, L., Coheur, P.-F., Prata, F., Hadji-Lazaro, J., Hurtmans, D., and Clerbaux, C.: A unified approach to infrared aerosol remote sensing and type specification, Atmos. Chem. Phys., 13, 21952221, doi:10.5194/acp-13-2195-2013, 2013.

Cziczo, D. J., Froyd, K. D., Hoose, C., Jensen, E. J., Diao, M., Zondlo, M. a, Smith, J. B., Twohy, C. H., and Murphy, D. M.: Clarifying the dominant sources and mechanisms of cirrus cloud formation, Science, 340, 1320-1324, doi:10.1126/science.1234145, 2013.

Davis, S. M., Liang, C. K., and Rosenlof, K. H.: Interannual variability of tropical tropopause layer clouds, Geophys. Res. Lett., 40, 2862-2866, doi:10.1002/grl.50512, 2013.

Doeringer, D., Eldering, A., Boone, C. D., González Abad, G., and Bernath, P. F.: Observation of sulfate aerosols and $\mathrm{SO}_{2}$ from the Sarychev volcanic eruption using data from the Atmospheric Chemistry Experiment (ACE), J. Geophys. Res., 117, D03203, doi:10.1029/2011JD016556, 2012.

Ebojie, F., von Savigny, C., Ladstätter-Weißenmayer, A., Rozanov, A., Weber, M., Eichmann, K.-U., Bötel, S., Rahpoe, N., Bovensmann, H., and Burrows, J. P.: Tropospheric column amount of ozone retrieved from SCIAMACHY limb-nadir-matching observations, Atmos. Meas. Tech., 7, 2073-2096, doi:10.5194/amt-72073-2014, 2014.

European Space Agency: Readme file for SCIAMACHY Level 2 version 5.02 products, Issue 1.2 (ENVI-GSOP-EOGD-QD-130118), 2013.

Fischer, H., Birk, M., Blom, C., Carli, B., Carlotti, M., von Clarmann, T., Delbouille, L., Dudhia, A., Ehhalt, D., Endemann, M., Flaud, J. M., Gessner, R., Kleinert, A., Koopman, R., Langen, J., López-Puertas, M., Mosner, P., Nett, H., Oelhaf, H., Perron, G., Remedios, J., Ridolfi, M., Stiller, G., and Zander, R.: MIPAS: an instrument for atmospheric and climate research, Atmos. Chem. Phys., 8, 2151-2188, doi:10.5194/acp-8-2151-2008, 2008.

Fueglistaler, S., Dessler, A., Dunkerton, T., Folkins, I., Fu, Q., and Mote, P.: Tropical Tropopause Layer, Rev. Geophys., 47, 1-31, doi:10.1029/2008RG000267, 2009.

Generoso, S., Bey, I., Labonne, M., and Breon, F.-M.: Aerosol vertical distribution in dust outflow over the Atlantic: Comparisons between GEOS-Chem and Cloud-Aerosol Lidar and Infrared Pathfinder Satellite Observation (CALIPSO), J. Geophys. Res., 113, D24209, doi:10.1029/2008JD010154, 2008.

Global Volcanism Program: Report on Rabaul (Papua New Guinea), in: Bulletin of the Global Volcanism Network, 
edited by: Wunderman, R., 31, 9, Smithsonian Institution, doi:10.5479/si.GVP.BGVN200609-252140, 2006.

Gottwald, M., Krieg, E., von Savigny, C., Noël, S., Bovensmann, H., and Bramstedt, K.: Determination of SCIAMACHY Line of Sight Misalignments, Proceedings of the Envisat Atmospheric Science Conference, ESA SP-636, Montreux, Switzerland, 2327 April 2007.

Gottwald, M., Krieg, E., Lichtenberg, G., Slijkhuis, S., von Savigny, C., Noël, S., Bovensmann, H., and Bramstedt, K.: The Status of the SCIAMACHY Line-of-Sight Pointing Knowledge, Proc. ESA Living Planet Symposium, 28 June-2 July 2010, SP-686, Bergen, Norway, 2010.

Gottwald, M. and Bovensmann, H.: SCIAMACHY - Exploring the Changing Earth's Atmosphere, Springer, Dordrecht, Heidelberg, London, New York, ISBN: 978-90-481-9895-5, 2011.

Greenhough, J., Remedios, J. J., Sembhi, H., and Kramer, L. J.: Towards cloud detection and cloud frequency distributions from MIPAS infra-red observations, Adv. Space Res., 36, 800-806, doi:10.1016/j.asr.2005.04.096, 2005.

Haywood, J. M., Jones, A., Clarisse, L., Bourassa, A., Barnes, J., Telford, P., Bellouin, N., Boucher, O., Agnew, P., Clerbaux, C., Coheur, P., Degenstein, D., and Braesicke, P.: Observations of the eruption of the Sarychev volcano and simulations using the HadGEM2 climate model, J. Geophys. Res., 115, D21212, doi:10.1029/2010JD014447, 2010.

Höpfner, M., Glatthor, N., Grabowski, U., Kellmann, S., Kiefer, M., Linden, A., Orphal, J., Stiller, G., von Clarmann, T., Funke, B., and Boone, C. D.: Sulfur dioxide $\left(\mathrm{SO}_{2}\right)$ as observed by MIPAS/Envisat: temporal development and spatial distribution at $15-45 \mathrm{~km}$ altitude, Atmos. Chem. Phys., 13, 10405-10423, doi:10.5194/acp-13-10405-2013, 2013.

IPCC, 2013: Climate Change 2013: The Physical Science Basis, in: Contribution of Working Group I to the Fifth Assessment Report of the Intergovernmental Panel on Climate Change, edited by: Stocker, T. F., Qin, D., Plattner, G.-K., Tignor, M., Allen, S. K., Boschung, J., Nauels, A., Xia, Y., Bex, V., and Midgley, P. M., Cambridge University Press, Cambridge, United Kingdom and New York, NY, USA, 1535 pp., doi:10.1017/CBO9781107415324, 2013.

Kaiser, J. W., von Savigny, C., Eichmann, K.-U., Noël, S., Bovensmann, H., Frerick, J., and Burrows, J. P.: Satellite-pointing retrieval from atmospheric limb-scattering of solar UV-B radiation, Can. J. Phys., 82, 1041-1052, doi:10.1139/p04-071, 2004b.

Koelemeijer, R. B. A., Stammes, P., Hovenier, J. W., and de Haan, J. F.: Global distributions of effective cloud fraction and cloud top pressure derived from oxygen A band spectra measured by the Global Ozone Monitoring Experiment: Comparison to ISCCP data, J. Geophys. Res., 107, 4151, doi:10.1029/2001JD000840, 2002.

Kokhanovsky, A. A.: Optical properties of terrestrial clouds, EarthSci. Rev., 64, 189-241, doi:10.1016/S0012-8252(03)00042-4, 2004.

Kokhanovsky, A. A., Rozanov, V. V., Burrows, J. P., Eichmann, K. U., Lotz, W., and Vountas, M.: The SCIAMACHY cloud products: Algorithms and examples from ENVISAT, Adv. Space Res., 36, 789-799, doi:10.1016/j.asr.2005.03.026, 2005.

Kokhanovsky, A. A., Jourdan, O., and Burrows, J. P.: The cloud phase discrimination from a satellite, IEEE Geosci. Remote Sens. Lett., 3, 103-106, doi:10.1109/LGRS.2005.858487, 2006.
Kravitz, B., Robock, A., Bourassa, A., Deshler, T., Wu, D., Mattis, I., Finger, F., Hoffmann, A., Ritter, C., Bitar, L., Duck, T. J., and Barnes, J. E.: Simulation and observations of stratospheric aerosols from the 2009 Sarychev volcanic eruption, J. Geophys. Res., 116, D18211, doi:10.1029/2010JD015501, 2011.

Langowski, M. P., von Savigny, C., Burrows, J. P., Feng, W., Plane, J. M. C., Marsh, D. R., Janches, D., Sinnhuber, M., Aikin, A. C., and Liebing, P.: Global investigation of the $\mathrm{Mg}$ atom and ion layers using SCIAMACHY/Envisat observations between 70 and $150 \mathrm{~km}$ altitude and WACCM-Mg model results, Atmos. Chem. Phys., 15, 273-295, doi:10.5194/acp-15-273-2015, 2015.

Leahy, L. V., Wood, R., Charlson, R. J., Hostetler, C. A., Rogers, R. R., Vaughan, M. A., and Winker, D. M.: On the nature and extent of optically thin marine low clouds, J. Geophys. Res.-Atmos., 117, 1-20, doi:10.1029/2012JD017929, 2012.

Lelli, L., Kokhanovsky, A. A., Rozanov, V. V., Vountas, M., Sayer, A. M., and Burrows, J. P.: Seven years of global retrieval of cloud properties using space-borne data of GOME, Atmos. Meas. Tech., 5, 1551-1570, doi:10.5194/amt-5-1551-2012, 2012.

Lelli, L.: Studies of global cloud field using measurements of GOME, SCIAMACHY and GOME-2, PhD thesis, IUP, 2013, available at: http://elib.suub.uni-bremen.de/edocs/00103470-1. pdf, 2013.

Lelli, L., Kokhanovsky, A. A., Rozanov, V. V., Vountas, M., and Burrows, J. P.: Linear trends in cloud top height from passive observations in the oxygen A-band, Atmos. Chem. Phys., 14, 56795692, doi:10.5194/acp-14-5679-2014, 2014.

Liebing, P., Bramstedt, K., Noël, S., Rozanov, V., Bovensmann, H., and Burrows, J. P.: Polarization data from SCIAMACHY limb backscatter observations compared to vector radiative transfer model simulations, Atmos. Meas. Tech., 6, 1503-1520, doi:10.5194/amt-6-1503-2013, 2013.

Liou, K. N.: Cirrus clouds and climate, McGraw-Hill 2005 Yearbook of Science and Technology, USA, 51-53, ISBN: 0639785511649, 2005.

Liu, D., Wang, Z., Liu, Z., Winker, D., and Trepte, C.: A height resolved global view of dust aerosols from the first year CALIPSO lidar measurements, J. Geophys. Res., 113, D16214, doi:10.1029/2007JD009776, 2008.

Massie, S., Gille, J., Khosravi, R., Lee, H., Kinnison, D., Francis, G., Nardi, B., Eden, T., Craig, C., Halvorson, C., Coffey, M., Packman, D., Cavanaugh, C., Craft, J., Dean, V., Ellis, D., Barnett, J., Hepplewhite, C., Lambert, A., Manney, G., Strawa, A., and Legg, M.: High Resolution Dynamics Limb Sounder observations of polar stratospheric clouds and subvisible cirrus, J. Geophys. Res., 112, D24S31, doi:10.1029/2007JD008788, 2007.

Mateshvili, N., Fussen, D., Mateshvili, G., Mateshvili, I., Vanhellemont, F., Kyrölä, E., Tukiainen, S., Kujanpää, J., Bingen, C., Robert, C., Tétard, C., and Dekemper, E.: Nabro volcano aerosol in the stratosphere over Georgia, South Caucasus from groundbased spectrometry of twilight sky brightness, Atmos. Meas. Tech., 6, 2563-2576, doi:10.5194/amt-6-2563-2013, 2013.

Mattis, I., Siefert, P., Müller, D., Tesche, M., Hiebsch, A., Kanitz, T., Schmidt, J., Finger, F., Wandinger, U., and Ansmann, A.: Volcanic aerosol layers observed with multiwavelength Raman lidar over central Europe in 2008-2009, J. Geophys. Res., 115, D00L04, doi:10.1029/2009JD013472, 2010.

Mülmenstädt, J., Sourdeval, O., Delanoë, J., and Quaas, J.: Frequency of occurrence of rain from liquid-, mixed-, and ice-phase 
clouds derived from A-Train satellite retrievals, Geophys. Res. Lett., 42, 6502-6509, doi:10.1002/2015GL064604, 2015.

Normand, E. N., Wiensz, J. T., Bourassa, A. E., and Degenstein, D. A.: Cloud discrimination in probability density functions of limb-scattered sunlight measurements, Atmos. Meas. Tech., 6, 3359-3368, doi:10.5194/amt-6-3359-2013, 2013.

Raspollini, P. and Ceccherini, S.: Configuration Management of MIPAS L2 Auxiliary Data Files, Tech note, TN-IFAC-GS0302, issue $6,2011$.

Remer, L. A., Kleidman, R. G., Levy, R. C., Kaufman, Y. J., Tanré, D., Mattoo, S., Martins, J. V., Ichoku, C., Koren, I., Yu, H., and Holben, B. N.: Global aerosol climatology from the MODIS satellite sensors, J. Geophys. Res., 113, D14S07, doi:10.1029/2007JD009661, 2008.

Reuter, M. and Pfeifer, S.: Moments from space captured by MSG SEVIRI, Int. J. Remote Sens., 32, 4131-4140, doi:10.1080/01431161.2011.566288, 2011.

Rossow, W. B. and Schiffer, R. A.: Advances in understanding clouds from ISCCP, B. Am. Meteorol. Soc., 80, 2261-2287, 1999.

Rozanov, A., Weigel, K., Bovensmann, H., Dhomse, S., Eichmann, K.-U., Kivi, R., Rozanov, V., Vömel, H., Weber, M., and Burrows, J. P.: Retrieval of water vapor vertical distributions in the upper troposphere and the lower stratosphere from SCIAMACHY limb measurements, Atmos. Meas. Tech., 4, 933-954, doi:10.5194/amt-4-933-2011, 2011.

Rozanov, V. V. and Kokhanovsky, A. A.: Semianalytical cloud retrieval algorithm as applied to the cloud top altitude and the cloud geometrical thickness determination from top-of-atmosphere reflectance measurements in the oxygen A band, J. Geophys. Res., 109, D05202, doi:10.1029/2003JD004104, 2004.

Rozanov, V. V., Rozanov, A. V., Kokhanovsky, A. A., and Burrows, J. P.: Radiative transfer through terrestrial atmosphere and ocean: Software package SCIATRAN, J. Quant. Spectrosc. R., 133, 1371, doi:10.1016/j.jqsrt.2013.07.004, 2014.

Sassen, K. and Cho, B. S.: Subvisual-Thin Cirrus Lidar Dataset for Satellite Verification and Climatological Research, J. Appl. Meteor., 31, 1275-1285, 1992.

Sassen, K., Wang, Z., and Liu, D.: Cirrus clouds and deep convection in the tropics: Insights from CALIPSO and CloudSat, J. Geophys. Res., 114, D00H06, doi:10.1029/2009JD011916, 2009.

Schmetz, J., Pili, P., Tjemkes, S., Just, D., Kerkmann, J., Rota, S., and Ratier, A.: An Introduction to Meteosat Second Generation (MSG), B. Am. Meteorol. Soc., 83, 977-992, doi:10.1175/15200477(2002)083<0977:AITMSG>2.3.CO;2, 2002.

Sembhi, H., Remedios, J., Trent, T., Moore, D. P., Spang, R., Massie, S., and Vernier, J.-P.: MIPAS detection of cloud and aerosol particle occurrence in the UTLS with comparison to HIRDLS and CALIOP, Atmos. Meas. Tech., 5, 2537-2553, doi:10.5194/amt-5-2537-2012, 2012.

Sonkaew, T., Rozanov, V. V., von Savigny, C., Rozanov, A., Bovensmann, H., and Burrows, J. P.: Cloud sensitivity studies for stratospheric and lower mesospheric ozone profile retrievals from measurements of limb-scattered solar radiation, Atmos. Meas. Tech., 2, 653-678, doi:10.5194/amt-2-653-2009, 2009.
Spang, R., Riese, M., Eidmann, G., Offermann, D., Pfister, L., and Wang, P. H.: CRISTA observations of cirrus clouds around the tropopause, J. Geophys. Res., 107, 8174, doi:10.1029/2001JD000698, 2002.

Spang, R., Remedios, J. J., Tilmes, S., and Riese, M.: MIPAS observation of polar stratospheric clouds in the Arctic 2002/2003 and Antarctic 2003 winters, Adv. Space Res., 36, 868-878, 2005.

Spang, R., Arndt, K., Dudhia, A., Höpfner, M., Hoffmann, L., Hurley, J., Grainger, R. G., Griessbach, S., Poulsen, C., Remedios, J. J., Riese, M., Sembhi, H., Siddans, R., Waterfall, A., and Zehner, C.: Fast cloud parameter retrievals of MIPAS/Envisat, Atmos. Chem. Phys., 12, 7135-7164, doi:10.5194/acp-12-71352012, 2012.

Stubenrauch, C., Rossow, W., Kinne, S., and the GEWEX cloud assessment group: Assessment of Global Cloud Datasets from Satellites report, WCRP Report No. 23, 2012.

Stubenrauch, C. J., Rossow, W. B., Kinne, S., Ackerman, S., Cesana, G., Chepfer, H., Di Girolamo, L., Getzewich, B., Guignard, A., Heidinger, A., Maddux, B. C., Menzel, W. P., Minnis, P., Pearl, C., Platnick, S., Poulsen, C., Riedi, J., Sun-Mack, S., Walther, A., Winker, D., Zeng, S., and Zhao, G.: Assessment of Global Cloud Datasets from Satellites: Project and Database Initiated by the GEWEX Radiation Panel, B. Am. Meteorol. Soc., 94, 1031-1049, doi:10.1175/BAMS-D-12-00117.1, 2013.

von Savigny, C., Kaiser, J. W., Bovensmann, H., Burrows, J. P., McDermid, I. S., and Leblanc, T.: Spatial and temporal characterization of SCIAMACHY limb pointing errors during the first three years of the mission, Atmos. Chem. Phys., 5, 2593-2602, doi:10.5194/acp-5-2593-2005, 2005.

von Savigny, C., Ulasi, E. P., Eichmann, K.-U., Bovensmann, H., and Burrows, J. P.: Detection and mapping of polar stratospheric clouds using limb scattering observations, Atmos. Chem. Phys., 5, 3071-3079, doi:10.5194/acp-5-3071-2005, 2005.

Wang, P.-H., Minnis, P., McCormick, M. P., Kent, G. S., and Skeens, K. M.: A 6-year climatology of cloud occurrence frequency from Stratospheric Aerosol and Gas Experiment II observations (1985-1990), J. Geophys. Res., 101, 29407, doi:10.1029/96JD01780, 1996.

Weigel, K., Rozanov, A., Azam, F., Bramstedt, K., Damadeo, R., Eichmann, K.-U., Gebhardt, C., Hurst, D., Kraemer, M., Lossow, S., Read, W., Spelten, N., Stiller, G. P., Walker, K. A., Weber, M., Bovensmann, H., and Burrows, J. P.: UTLS water vapour from SCIAMACHY limb measurementsV3.01 (2002-2012), Atmos. Meas. Tech., 9, 133-158, doi:10.5194/amt-9-133-2016, 2016.

Winker, D. M. and Trepte, C. R.: Laminar cirrus observed near the tropical tropopause by LITE, Geophys. Res. Lett., 25, 33513354, doi:10.1029/98GL01292, 1998.

Winker, D. M., Vaughan, M. A., Omar, A., Hu, Y., Powell, K. A., Liu, Z., Hunt, W. H., and Young, S. A.: Overview of the CALIPSO mission and CALIOP data processing algorithms, J. Atmos. Ocean. Techn., 26, 2310-2323, doi:10.1175/2009JTECHA1281.1, 2009. 